\title{
Dispersal spectrum of four forest types along an altitudinal range of the Brazilian Atlantic Rainforest
}

\author{
Valéria Forni Martins ${ }^{1,2,3,5}$, Lara Priscila Domingues Cazotto ${ }^{4}$ \& Flavio Antonio Maës dos Santos ${ }^{2}$ \\ ${ }^{1}$ Programa de Pós-graduação em Ecologia, Institute of Biology, CP 6109, University of Campinas - \\ UNICAMP, 13083-970, Campinas, SP, Brazil. www.unicamp.br \\ ${ }^{2}$ Department of Plant Biology, Institute of Biology, CP 6109, University of Campinas - UNICAMP, 13083- \\ 970, Campinas, SP, Brazil. www.unicamp.br \\ ${ }^{3}$ Current address: Departamento de Ciências da Natureza, Matemática e Educação, Centro de Ciências \\ Agrárias, CP 153, Universidade Federal de São Carlos-UFSCar, 13600-970, Araras, SP, Brazil. www.cca. \\ ufscar.br \\ ${ }^{4}$ Graduação em Ciências Biológicas, Institute of Biology, CP 6109, University of Campinas - UNICAMP, \\ 13083-970, Campinas, SP, Brazil. www.unicamp.br \\ ${ }^{5}$ Corresponding author: e-mail: valeriafm@gmail.com
}

MARTINS, V.F., CAZOTTO, L.P.D., SANTOS, A.M.S. Dispersal spectrum of four forest types along an altitudinal range of the Brazilian Atlantic Rainforest. Biota Neotropica. 14(1): e20130003. http://www. biotaneotropica.org.br/v14n1/en/abstract?article+bn00614012014

\begin{abstract}
In ecological communities, the proportion of plant species with different dispersal syndromes is known as the dispersal spectrum, which can result from different selective pressures such as climate. This is because variations in temperature, humidity, atmospheric pressure and precipitation result in distinct flora and fauna among different sites. If climate conditions along an altitudinal range act as a strong direct or indirect selective pressure on dispersal syndromes, the dispersal spectrum among plant communities in different altitudes should be distinct. We organized the dispersal syndromes in five hierarchical levels according to the levels of detail in diaspore morphology and, consequently, different degrees of specificity to the dispersers. Then we identified, within each hierarchical level, the syndromes of tree species of four forest types of the Atlantic Rainforest along a $1200 \mathrm{~m}$ altitudinal range in Southeast Brazil. Among 327 species, we found two syndromes in the most general hierarchical level (abiotic and biotic dispersal), three in the following level (wind, self and animal), three in the intermediate level (barochory, autochory and endozoochory), two in the forth level (mammal and bird), and 12 syndromes in the most specific level, all of which were related to the morphology of diaspores dispersed by wind, autochory, mammals and birds. The dispersal spectrum in the five hierarchical levels was similar among the four forest types. Overall, the majority of species is dispersed by biotic agents, considered here as animals and the parent plant itself. Within biotic agents, the most important are animals, specifically birds. Most bird-dispersed species present drupoid diaspores. Our results indicate that the selective pressures on dispersal syndromes originated from climate conditions that vary with altitude are not strong, hence resulting in the same dispersal spectrum among the forest types.

Keywords: animal dispersal, biotic dispersal, bird dispersal, hierarchy of classification of dispersal syndromes.
\end{abstract}

MARTINS, V.F., CAZOTTO, L.P.D., SANTOS, A.M.S. Espectro de dispersão de quatro formações florestais ao longo de um gradiente altitudinal da Mata Atlântica brasileira. Biota Neotropica. 14(1): e20130003. http://www.biotaneotropica.org.br/v14n1/pt/abstract?article+bn00614012014

Resumo: Dentro de uma comunidade, a proporção de espécies vegetais com diferentes síndromes de dispersão é chamada de espectro de dispersão, o qual pode resultar de distintas pressões seletivas, como o clima. Isso ocorre porque variações na temperatura, umidade, pressão atmosférica e precipitação resultam em flora e fauna distintas entre locais. Assim, podemos esperar que o espectro de dispersão de comunidades vegetais em diferentes altitudes seja distinto se as condições climáticas ao longo do gradiente altitudinal atuarem como pressão seletiva direta ou indireta sobre as síndromes. Nós hierarquizamos as síndromes de dispersão em cinco níveis, de acordo com o detalhamento da morfologia dos diásporos e, consequentemente, seus diferentes graus de especificidade com os dispersores. Identificamos, em cada um dos níveis hierárquicos, as síndromes de espécies arbóreas de quatro formações florestais da Mata Atlântica ao longo de um gradiente altitudinal de $1200 \mathrm{~m}$ no sudeste do Brasil. Entre 327 espécies, encontramos duas síndromes no nível hierárquico mais geral (dispersão 
abiótica e biótica), três no nível seguinte (vento, própria planta parental e animais), três no nível intermediário (barocoria, autocoria e endozoocoria), duas no quarto nível (mamíferos e aves) e 12 síndromes no nível mais específico, relacionadas à morfologia dos diásporos dispersos pelo vento, autocoria, mamíferos e aves. O espectro de dispersão nos cinco níveis foi similar nas quatro formações florestais. De forma geral, a maior parte das espécies é dispersa por agentes bióticos, aqui considerados animais e a própria planta parental. Dentre os agentes bióticos, os mais importantes são os animais, especificamente as aves. A maioria das espécies dispersas pelas aves apresenta diásporos drupóides. Nossos resultados indicam que as pressões seletivas sobre as síndromes de dispersão ocasionadas pelas condições climáticas que variam com a altitude não são fortes. Assim, a ausência destas pressões seletivas resulta em um espectro de dispersão similar entre as formações florestais em diferentes altitudes.

Palavras-chave: dispersão biótica, hierarquia de classificação das síndromes de dispersão, ornitocoria, zoocoria.

\section{Introduction}

Seeds, fruits, infructescences and other dispersal units are generically called diaspores. Diaspore dispersal is a dynamic process of diaspore transportation away from the parent plant. This transportation can be performed by biotic agents, such as animals and the parent plant itself, or by abiotic agents, such as wind and water (van der Pijl 1972). Diaspores generally show adaptations for dispersal by a specific agent (Willson et al. 1990), which is known as dispersal syndrome. Therefore, the syndromes indicate the most likely primary dispersal agent of a particular plant species (van der Pijl 1972).

Dispersal syndromes have been extensively described by Ridley (1930) and van der Pijl (1972). For example, within biotic dispersal syndromes, animal-dispersed diaspores can be either fleshy or dry. Many different types of animals consume the former, which is known as endozoochory; the latter cling externally to the body of animals, a form of dispersal known as epizoochory. Endozoochorous diaspores present characteristics that are specifically attractive to particular groups of animals, such as ants (although they transport diaspores externally to their bodies to later remove their fleshy portion inside the nest), fishes, reptiles, birds or mammals. Conversely, mammaldispersed diaspores present characteristics that result in their dispersal by distinct groups of mammals (Ridley 1930, van der Pijl 1972). Therefore, there are different levels of detail in diaspore morphology and, consequently, different degrees of specificity to the dispersers. In the given example, biotic agents would be considered level 1 in a hierarchical classification of dispersal syndromes, as well as abiotic agents; animal dispersal would be level 2, as well as self dispersal by the parent plant and the abiotic dispersal by water and wind; endozoochory and epizoochory would both be level 3, as well as different forms of self dispersal (autochory and barochory); ant, fish, reptile, bird and mammal dispersal would all be level 4 , and dispersal by the distinct groups of mammals would be level 5 in the hierarchy, as well as the different forms of autochory, water and wind dispersal (for a more detailed explanation of the dispersal syndromes please see the "Protocol for the classification of dispersal syndromes" at supplementary material 1).

Despite the clear hierarchical organization of the dispersal syndromes, no author has yet proposed formal hierarchical levels within them. This organization is needed in studies that compare dispersal distances, demographic consequences of dispersal (e.g., the spatial distribution of seeds and seedlings) or the proportion of species with different dispersal syndromes in ecological communities. Restraining diaspore morphology and consequently its most likely dispersal agent should enable the evaluation of underlying patterns of dispersal opposed to the great variation that emerges when syndromes from different hierarchical levels are considered.

Birds are important dispersal agents, particularly in the tropics (Gentry 1982, Willson et al. 1989, Pedroni 2001). The diaspores they eat show very different morphologies, such as seeds with fleshy appendage, seeds without any nutritional reward (known as mimetic seeds), and fleshy fruits with few up to many seeds (i.e. drupoid and baccoid diaspores, respectively). Seeds with fleshy appendages, seeds without any nutritional reward and seeds from drupoid diaspores are larger than seeds from baccoid diaspores. Thus, the former may only be dispersed by large-bodied birds (Wheelwright 1985), which can swallow the whole diaspore and carry the large seed(s). Small birds can sometimes swallow large diaspores, but they are less willing or able to carry the mass of ballast associated with large seeds (Mack 1993). Therefore, small birds are most likely to only peck at the pulp of large diaspores and do not act as dispersers of large seeds. On the other hand, seeds from baccoid diaspores can be dispersed by both small and large birds, with the number of seeds carried varying with the size of the bird in relation to the size of the diaspore, which may be swallowed whole or have a portion pecked at. Therefore, the different types of bird-dispersed diaspores are likely to present dissimilar patterns of seed deposition in the environment as well as distinct implications for seed germination and establishment of the new individuals (Howe et al. 1985). Because of the different selective pressures on each type of bird-dispersed diaspore, it is necessary to divide them into different groups into level 5 of the hierarchy of dispersal syndromes.

Even though it is relatively easy to identify seed dispersal syndromes based on diaspore morphology alone, not necessarily can we predict which agent is actually acting as a disperser. This is especially critical for animal dispersal, since seed dispersal mutualisms are clearly unspecialized (Herrera 1985, 2002). Most plants lack attributes that require special handling by particular species of animals (Herrera 2002, Burns et al. 2009, but see Moran et al. 2004); thus, dispersers rarely show preferences for particular diaspore traits and often consume seeds and fruits indiscriminately (e.g., Herrera 1985, Burns et al. 2009, but see Carlo et al. 2003). Nevertheless, specialized relationships can arise on coarser taxonomic scales, among wide 'guilds' of diaspores and animals (Lomáscolo et al. 2008, Hollander \& Vander Wall 2009, but see Fischer \& Chapman 1993). This suggests that the diaspore morphology described in syndromes belonging to upper levels of the hierarchy proposed herein can be used with good reliability to predict the set of dispersal agents of a given plant species. On the other hand, 
biotic syndromes in levels 4 and 5 may hardly correspond to the actual set of dispersal agents.

This may be considered a shortcoming for the widespread use of dispersal syndromes, especially the ones in the lower levels of the hierarchy. Nevertheless, diaspore morphology is likely to restrict the agents that act as real dispersers, unregard of their taxonomic group, and these dispersers may deposit seeds in the environment in similar fashion. For instance, many diaspores with characteristics considered attractive to birds are also consumed by mammals. Because seeds belonging to drupoid diaspores are larger than those belonging to baccoid diaspores, the former are only likely to be dispersed by large birds and mammals (Wheelwright 1985), while the latter can be dispersed by both small and large animals. Large animals have larger home ranges (Kelt \& Van Vuren 2001) and may carry seeds over longer distances than smaller animals (Seidler \& Plotkin 2006). As a consequence, seeds belonging to drupoid diaspores may be deposit more scattered in the environment than seeds from baccoid diaspores, which may show some clumping due to dispersal by small animals. Hence, diaspores with similar morphology should be linked to the similar demographic consequences of seed dispersal, mediated by different dispersal agents. Because of that, we believe that the biotic syndromes proposed in levels 4 and 5 should be considered in studies of dispersal syndromes.

In ecological communities, the proportion of plant species with different dispersal syndromes is known as the dispersal spectrum (van der Pijl 1972, Hughes et al. 1994), which can result from different selective pressures. The main pressures on dispersal strategies arise from frugivores (Mazer \& Wheelwright 1993, Lord 2004), predation, competition among plant species for the same dispersers, climate seasonality and the environment in which the plants occur (Roth 1987, Almeida-Neto et al. 2008). Thus, forest types at different altitudes may have different dispersal spectra due to variations in temperature, humidity, atmospheric pressure and precipitation (Willson et al. 1990), all of which result in distinct flora and fauna along an altitudinal range.

The state park "Parque Estadual da Serra do Mar" (PESM hereafter), Southeast Brazil, is the largest continuous stretch of preserved Atlantic Rainforest in Brazil and extends from sea level to $1200 \mathrm{~m}$ of altitude (SOS Mata Atlântica/INPE/ISA 1998, Alves et al. 2010). Therefore, it is an excellent site for the investigation of dispersal spectrum changes with altitude. Both temperature and rainfall decrease with increasing altitude (Banco de Dados Climáticos do Brasil), and the different climate along the altitudinal range has resulted in distinct forest types, each with its own floristic composition (Joly et al. 2012). Therefore, we should also expect changes in the dispersal spectrum along the altitudinal range due to selective pressures imposed by climate on seed dispersal mechanisms.

As other tropical forests, the Atlantic Rainforest presents $45 \%$ up to $90 \%$ of shrub and/or tree species dispersed by animals (Pedroni 2001, Almeida-Neto et al. 2008). Animal dispersal is positively related to rainfall and hence tends to be more common at low altitudes (Willson et al. 1989, Vicente et al. 2003). However, Almeida-Neto et al. (2008) found that animal dispersal in the Atlantic Rainforest is negatively related to temperature, which suggests the importance of seed dispersal by animals may actually increase with increasing altitude. Therefore, the relation between animal dispersal and altitude should be further explored in order to depict the relative importance of rainfall and temperature on the dispersal spectrum.
Within endozoochorous species, bird dispersal is more common than mammal dispersal (Gentry 1982, Willson et al. 1989). In a $1900 \mathrm{~m}$ altitudinal range of the Atlantic Rainforest, Almeida-Neto et al. (2008) found predominance of birddispersed species at higher altitudes, while mammal-dispersed species were more frequent at lower altitudes. Last, within abiotic dispersal, wind and self-dispersed species are more frequent at higher altitudes, where the climate is drier and vegetation more open (van der Pijl 1972, Campassi 2006). Although some studies have shown the influence of climate on dispersal spectrum changes with altitude, the detailed hierarchical levels within dispersal syndromes we previously described have never been taken into account.

This study aimed to (1) develop a hierarchical organization of dispersal syndromes for tree species, which include four divisions within bird dispersal based on diaspore morphology, and (2) identify the syndromes within each hierarchical level for tree species of four forest types along the altitudinal range of PESM. After identifying the syndromes, we determined the dispersal spectrum within each hierarchical level in the four forest types. Then we specifically asked whether the dispersal spectrum differed among the forest types.

We expect that dispersal by biotic agents, mainly by animals that consume diaspores and specifically by birds, should prevail among tree species at PESM, as found in other studies carried out in the Brazilian Atlantic Rainforest (e.g., Pedroni 2001, Campassi 2006, Kinoshita et al. 2006, Almeida-Neto et al. 2008, Silva \& Rodal 2009). However, differently from previous studies, the dispersal spectrum within different hierarchical levels of the dispersal syndromes will be used, including the divisions within bird-dispersed diaspores. We hypothesize that, if climate conditions along the altitudinal range of PESM act as a strong selective pressure on dispersal syndromes, there should be differences in the dispersal spectrum among the forest types. For example, if rainfall imposes a stronger pressure, animal dispersal should be more common at lower altitudes. On the other hand, if temperature imposes a stronger pressure, animal dispersal should be more common at higher altitudes. The differences found in the dispersal spectrum along the altitudinal range should reflect the key importance of certain dispersal agents in the different environments, as found by other authors (e.g., van der Pijl 1972, Roth 1987, Willson et al. 1990, Hughes et al. 1994, Pedroni 2001, Campassi 2006, Almeida-Neto et al. 2008).

\section{Material and Methods}

\section{Study site}

The Brazilian Atlantic Forest is considered one of the world's hotspots for biodiversity conservation (Myers et al. 2000 ), with only about $12 \%$ of its original cover remaining in fragments larger than 3 ha (Fundação SOS Mata Atlântica). The largest continuous remnant includes the state park PESM $\left(23^{\circ} 34^{\prime}-23^{\circ} 17^{\prime} \mathrm{S}\right.$ e $\left.45^{\circ} 02^{\prime}-45^{\circ} 11^{\prime} \mathrm{W}\right)$, which encompasses the mountain range of "Serra do Mar" along the northern coast of the state of São Paulo, SE Brazil. PESM comprises 315,000 ha (SOS Mata Atlântica/INPE/ISA 1998) ranging from $0 \mathrm{~m}$ to $1200 \mathrm{~m}$ above sea level (a.s.1.; Alves et al. 2010). The geological and topological complexity of "Serra do Mar" results in extremely heterogeneous habitats and microclimates (Suguio \& Martin 1978, Alves et al. 2010), reflected in the different forest types present at the study site (Alves et al. 2010, Joly et al. 2012). 
In 2006-2007, researchers from the Theme Project "Functional Gradient" (Biota/FAPESP 03/12595-7) installed 14 non-contiguous, permanent 1 ha plots at the four forest types present along the altitudinal range of PESM. Plot establishment and tree sampling followed the RAINFOR field manual (Phillips et al. 2009, Joly et al. 2012). One plot was placed at the Restinga Forest (up to $10 \mathrm{~m}$ a.s.l. in sandy soil; Restinga hereafter), five plots at the Lowland Atlantic Rainforest (between $5 \mathrm{~m}$ and $50 \mathrm{~m}$ a.s.l.; Lowland hereafter), four plots at the Submontane Atlantic Rainforest (between $50 \mathrm{~m}$ and $500 \mathrm{~m}$ a.s.1.; Submontane hereafter) and four plots were installed at the Montane Atlantic Rainforest (between $500 \mathrm{~m}$ and $1200 \mathrm{~m}$ a.s.l.; Monane hereafter; Veloso et al. 2001, Joly et al. 2012). In this study, we collected data at one plot of each forest type. Because floristic composition and community structure are very similar among plots installed at the same forest type (Joly et al. 2012), we believe the results presented further are representative of the different forest types of the Atlantic Rainforest at the study site.

At the low portion of "Serra do Mar", mean temperatures range from $18.4^{\circ} \mathrm{C}$ in July to $25.5^{\circ} \mathrm{C}$ in February. A dry season is absent and mean rainfall ranges from $11 \mathrm{~mm}$ in July to 376 $\mathrm{mm}$ in January. At the high portion of "Serra do Mar", mean temperatures are a little lower and range from $16.4^{\circ} \mathrm{C}$ in July to $23.2^{\circ} \mathrm{C}$ in February. Again, a dry season is absent, but there is less rainfall than at the low portion of the mountain range (278 $\mathrm{mm}$ in February and $20 \mathrm{~mm}$ in July; EMBRAPA). Nevertheless, Submontane and Montane are frequently covered by clouds and mist brought by oceanic winds (Silva-Dias et al. 1995), which increase humidity but reduce light availability to plants (Sousa Neto 2008).

Soils along the altitudinal range are shallow and nutrient poor. However, the soil of Restinga is sandier and poorer than the soils of the other forest types (Martins 2010). Soil humidity, total carbon and nitrogen, and ammonia and nitrate concentrations increase with altitude. Conversely, decomposition rates, and $\mathrm{N}_{2} \mathrm{O}$ and $\mathrm{CO}_{2}$ emissions from the soil to the atmosphere decrease with altitude (Sousa Neto 2008).

\section{Species studied}

The researchers from the Theme Project sampled, collected and identified every living tree (including palms) with stem $\mathrm{DBH} \geqslant 4.8 \mathrm{~cm}$ inside the 14 plots. Voucher specimens are deposited in the herbariums of the University of Campinas (UEC), "Instituto Agronômico de Campinas" (IAC) and "Universidade Estadual Paulista "Júlio de Mesquita Filho", campus Rio Claro (HRCB; Joly et al. 2012).

We identified the dispersal syndrome within all hierarchical levels of the species sampled at the four study plots. Unidentified individuals at the family level and lacking diaspores in the voucher material were not included in the analysis. Undetermined species of known families had their dispersal syndrome assigned when the families had only one syndrome. Conversely, we were unable to identify the syndrome of undetermined species belonging to families with more than one syndrome, except in cases where the diaspores had been collected. Therefore, the syndrome of undetermined species with different types of diaspores in the same family was described as non-identified (NI hereafter).

\section{Dispersal syndromes}

We conducted a review of the syndromes that occur at tree species and elaborated a protocol of identification where the references used can be found ("Protocol for the classification of dispersal syndromes" at supplementary material 1). The diaspore characteristics presented were extracted from specialized literature rather than based on fruits and seeds of the species studied. This makes our classification wide enough to be used by other authors and at other study systems. Based on the protocol, we also prepared a diagram (Figure 1) that establishes the hierarchical classification of the dispersal syndromes in five levels, each composed of several groups.

We created four divisions within bird dispersal based on the following morphological characteristics: (1) seeds with sarcotesta, fleshy aril or ariloid structures; (2) seeds with colours that mimics external fleshy appendages or a juicy aspect; (3) few or many seeds per diaspore, and (4) size of seeds in relation to the diaspore. As a result, the divisions created were seeds with fleshy appendage, seeds without any nutritional reward, drupoid diaspores and baccoid diaspores (Figure 1).

Diaspores dispersed by mammals present very different morphologies and are attractive to distinct groups of mammals. Because of that, syndromes of mammal-dispersed diaspores originally received their names according to the taxonomic group of animals that act as the dispersal agent (e.g., Ridley 1930, van der Pijl 1972, Janzen \& Martin 1982, Herrera 1989). However, in the classification here proposed, all other groups belonging to level 5 were designated based on the morphology of the diaspores, such as those previously described for bird dispersal. So, in order for all groups of level 5 to have the same classification criteria, we proposed new terms for the syndromes of mammal dispersal. The new terms were based on the main morphological characteristics of the diaspores in each mammal-dispersed group, which may be related to a taxonomic group of dispersal agent (Figure 1).

As one can note in Figure 1, some dispersal syndromes are unfiled to all hierarchical levels. For example, within abiotic dispersal syndromes (level 1), both wind and water-dispersed diaspores (level 2) reach a high level of detail without showing intermediate levels. In the case of wind dispersal, there are dust, balloon, plumed, winged, ballist and roller diaspores (van der Pijl 1972). We prefer to file them directly to level 5 instead of 3 because they present very specific morphology that, analogously to biotically dispersed diaspores, enables their classification into the more detailed level of the hierarchy. The lack of intermediate levels for abiotic dispersal may suggest that the diversification of diaspore morphology resulting from selective pressures imposed by biotic agents is greater than those imposed by abiotic agents.

To identify the dispersal syndromes, we observed the morphological characteristics of diaspores in the voucher material deposited in the Herbarium UEC. Since few species were collected with diaspores, we also used plant images and drawings, type descriptions in the literature, and/or material collected outside PESM. Even though diaspores may be dispersed by animals belonging to different taxonomic groups, we based our classification on the dispersal syndromes proposed by Ridley (1930) and van der Pijl (1972), and, more specifically, on diaspore morphology. Though many species are subject to secondary dispersal by animals or water, for the purpose of this study we examined only the primary phase of dispersal (Seidler \& Plotkin 2006).

\section{Data analysis}

We used chi-square tests to compare the frequency of occurrence of syndromes within each hierarchical level among 

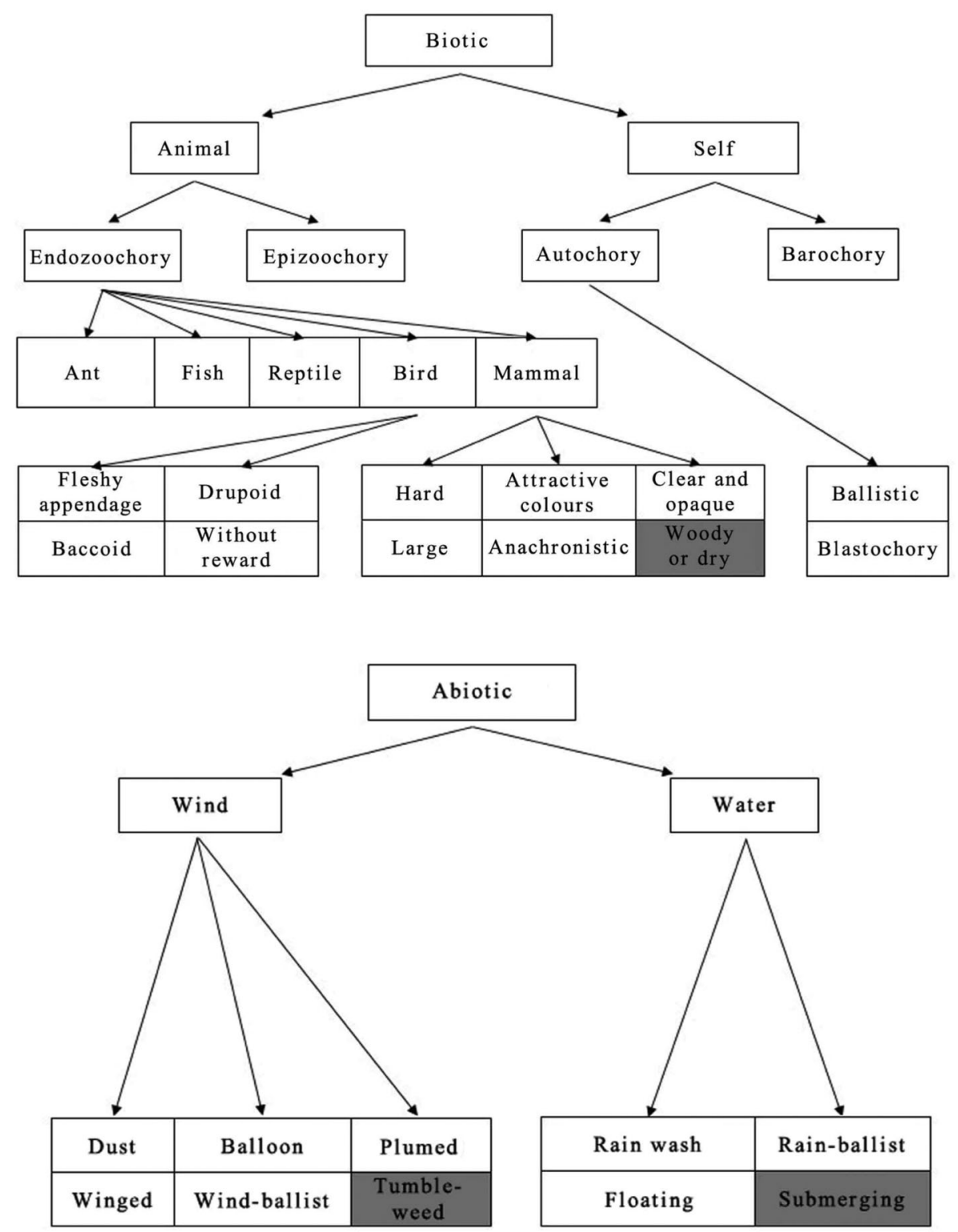

Figure 1. Diagram with five hierarchical levels of dispersal syndromes. Syndromes in grey boxes are those that definitely do not occur in tree species. For further explanation, please see the "Protocol for the classification of dispersal syndromes" at supplementary material 1.

the four forest types. The expected values for each level were the total number of species with identified syndromes in the four forest types together divided by the number of syndromes within the hierarchical level. We also used chi-square tests to compare the frequency of occurrence of syndromes within each hierarchical level in each of the four forest types. The expected values for level 1 were the total number of species with identified syndromes divided by two (biotic and abiotic dispersal). The expected values for further hierarchical levels were based on the proportion of species belonging to syndromes from the upper level. For example, for level 2, the expected values of animal and self dispersal were the number of biotically dispersed species divided by two, and the expected values of wind and water dispersal were the number of abiotically dispersed species divided by two. We did not perform any comparison among the syndromes of level 3, because all animal-dispersed species (level 2) presented endozoochorous diaspores (level 3), and the syndromes of epizoochory, autochory and barochory (all level 3) were represented by less than five species. For level 5, we performed chi-square tests for the different types of bird-dispersed diaspores alone, for the different types of mammal-dispersed diaspores alone, and for all types of bird, mammal and winddispersed diaspores together. All tests were performed for categories with sample size of at least five species, with $\alpha=0.05$ (Zar 1999).

\section{Results}

We listed 83 species at Restinga, 137 at Lowland, 149 at Submontane and 144 at Montane. Because some species occurred in more than one forest type, we obtained a final list with 327 species for the four study plots. Within these species, one was NI at Restinga (corresponding to $1.2 \%$ of the species in this forest type), three were NI at Lowland $(2.2 \%)$, three were undetermined at Montane $(2.1 \%)$ and 13 were NI at 
Table 1. Comparisons of the frequency of occurrence of dispersal syndromes within the same hierarchical level (please see Figure 1) among four forest types of the Atlantic Rainforest in SE Brazil. In all cases, d.f. = 3, except for the last comparison where d.f. = 12. Tabela 1: Comparações da frequência de ocorrência das síndromes de dispersão de um mesmo nível hierárquico (favor ver Figura 1) entre quatro tipos florestais da Mata Atlântica no sudeste do Brasil. Em todos os casos, g.l. = 3, com exceção da última comparação, na qual g.l. = 12 .

\begin{tabular}{lcc}
\hline Syndromes & $\chi^{2}$ & $P$ \\
\hline Level 1: abiotic agents x biotic agents & 4.07 & 0.25 \\
Level 2: wind x animal & 4.05 & 0.26 \\
Level 4: mammal x bird & 0.66 & 0.88 \\
Level 5: seeds with fleshy appendage attached x drupoid diaspores & 0.29 & 0.96 \\
Level 5: diaspores with attractive colours x (hard + clear and opaque + large diaspores) & 3.15 \\
Level 5: seeds with fleshy appendage attached x drupoid diaspores x diaspores with attractive & 4.88 \\
colours x (hard + clear and opaque + large diaspores) x winged diaspores & 0.37 \\
\hline
\end{tabular}

Montane (9.0\%). The list of all tree species sampled at the four forest types and their dispersal syndromes belonging to the five hierarchical levels proposed herein can be found at supplementary material 2.

As one travels through the diagram that organizes the hierarchical levels of the dispersal syndromes (Figure 1), the variation in diaspore morphology and in the group of dispersal agent decreases from the upper to the lower levels. As a result, the characteristics of the syndromes become more specific from the upper to the lower levels.

The frequency of occurrence of dispersal syndromes within each of the five hierarchical levels did not differ among the four forest types $(P>0.05$; Table 1).The overall dispersal spectrum of the Atlantic Rainforest at PESM presents more species dispersed by biotic agents, mainly animals that consume diaspores and specifically birds, which disperse drupoid diaspores (Figure 2).

Species were dispersed 6.8 to 15.8 times more by biotic than by abiotic agents $\left(\chi^{2}=338.10, P<0.001\right.$, d.f. $\left.=3\right)$. The frequency of animal dispersal was higher and that of wind dispersal lower than expected based on the proportion of species dispersed by biotic and abiotic agents, respectively $\left(\chi^{2}=\right.$ $244.37, P<0.001$, d.f. $=3$ ). Wind dispersal was the only abiotic syndrome found in the forest types. Among animal-dispersed species, bird dispersal was 2.7 to 3.5 times more common than mammal dispersal $\left(\chi^{2}=117.86, P<0.001\right.$, d.f. $=3$; Figure 3$)$.

Within bird dispersal, there was 3.3 to 4 times more drupoid diaspores than seeds with fleshy appendage attached $\left(\chi^{2}=\right.$ 324.78, $P<0.001$, d.f. $=3$ ). Within mammal dispersal, there was 1.8 to 4.7 times more diaspores with attractive colours (corresponding to those attractive to primates) than hard (rodents), clear and opaque (bats), and large diaspores (Carnivora) together $\left(\chi^{2}=168.17, P<0.001\right.$, d.f. $=3$; Table 2). For further explanation on names, please see the "Protocol for the classification of dispersal syndromes" at supplementary material 1.

Considering all syndromes of level 5, drupoid diaspores, diaspores with attractive colours and winged diaspores occurred at higher frequencies than expected based on the proportion of bird, mammal and wind-dispersed species respectively. Seeds with fleshy appendage attached occurred at a similar frequency to the expected based on the proportion of bird-dispersed species. Conversely, hard, clear and opaque, and large diaspores occurred less frequently than expected based on the proportion of mammal-dispersed species $\left(\chi^{2}=\right.$ 563.81, $P<0.001$, d.f. $=12$; Table 2).

\section{Discussion}

In this study, we propose five hierarchical levels for the classification of dispersal syndromes based entirely on diaspore morphology. Using this classification, we found a similar dispersal spectrum along the altitudinal range of PESM, which is contrary to the expectation based on previous studies carried on the Atlantic Rainforest and elsewhere (e.g., van der Pijl 1972, Roth 1987, Willson et al. 1990, Hughes et al. 1994, Pedroni 2001, Almeida-Neto et al. 2008). Even though climate is an important determinant of floristic composition along the altitudinal range (Joly et al. 2012), it probably does not act as a strong selective pressure on dispersal syndromes, hence resulting in the same dispersal spectrum among the forest types. Alternatively, the selective pressures imposed by rainfall and temperature may counteract each other and result in a similar dispersal spectrum along the altitudinal range. Future studies should also investigate whether the main groups of animal dispersers change along the altitudinal range, so the dispersal spectrum can be correlated with the dispersers at the study site.

Almost 90\% of tree species at PESM are dispersed by biotic agents, particularly animals, which is the highest proportion of animal dispersal described for tropical forests elsewhere (Pedroni 2001, Kinoshita et al. 2006, Almeida-Neto et al. 2008, Silva \& Rodal 2009). This great proportion of animaldispersed species at PESM is likely to be related to high rainfall throughout the year in the mountain range of "Serra do Mar" and the high abundance of vertebrate frugivores in tropical forests (Gentry 1982, Willson et al. 1989, Vicente et al. 2003, Almeida-Neto et al. 2008). Most animal-dispersed species at PESM are attractive to birds, as described in other studies (Gentry 1982, Willson et al. 1989, Almeida-Neto et al. 2008). Nevertheless, bird dispersal is 2.7 to 3.5 times more frequent than mammal dispersal at our study site, which is a much higher proportion than the previous described 2:1 for the Neotropics (Gentry 1982, Almeida-Neto et al. 2008). Bird dispersal is likely to have great implications for seed deposition patterns and, consequently, for plant demography. This is because these animals deposit high quantities of seeds in specific sites (Debussche \& Isenmann 1994, Takahashi \& Kamitani 2004), such as near plants with many fruit (Pizo \& Almeida-Neto 2009), taller plants that enable birds to better visualize both preys and predators (McDonnell 1986, Debussche \& Isenmann 1994), and forest gaps (Debussche \& Isenmann 1994, but also see Loiselle et al. 1996 and Martini \& Santos 2007). 
A

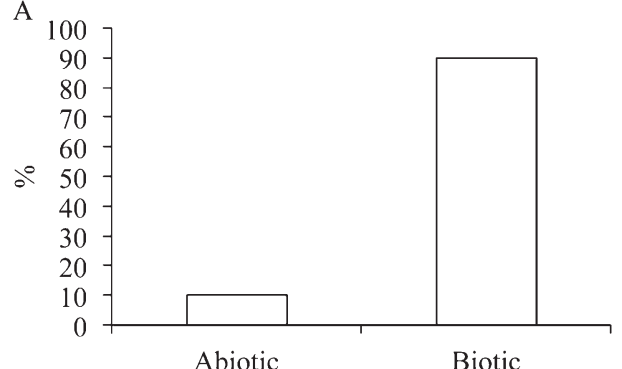

$\mathrm{C}$

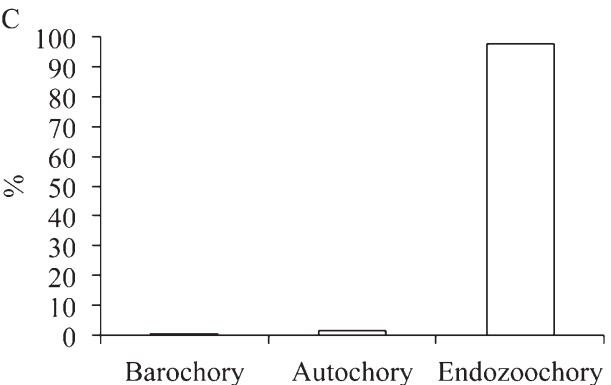

$\mathrm{E}$

E 100
B

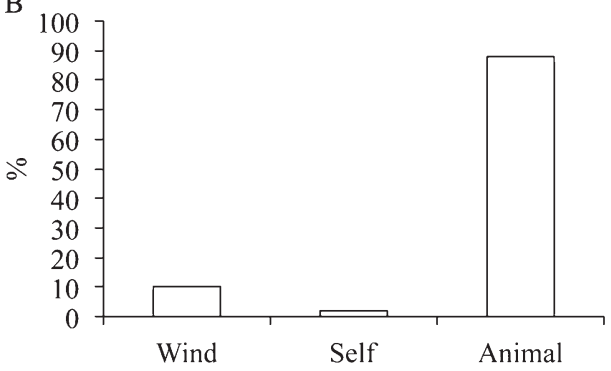

$\mathrm{D}$

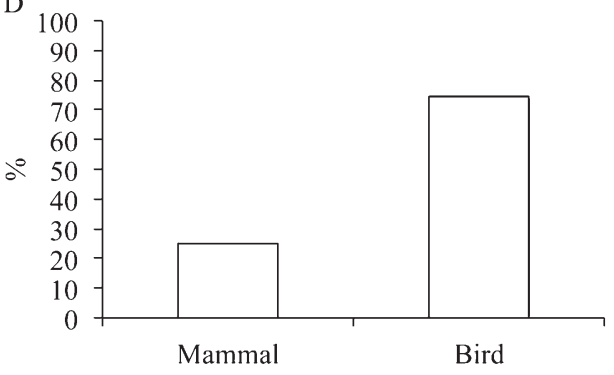

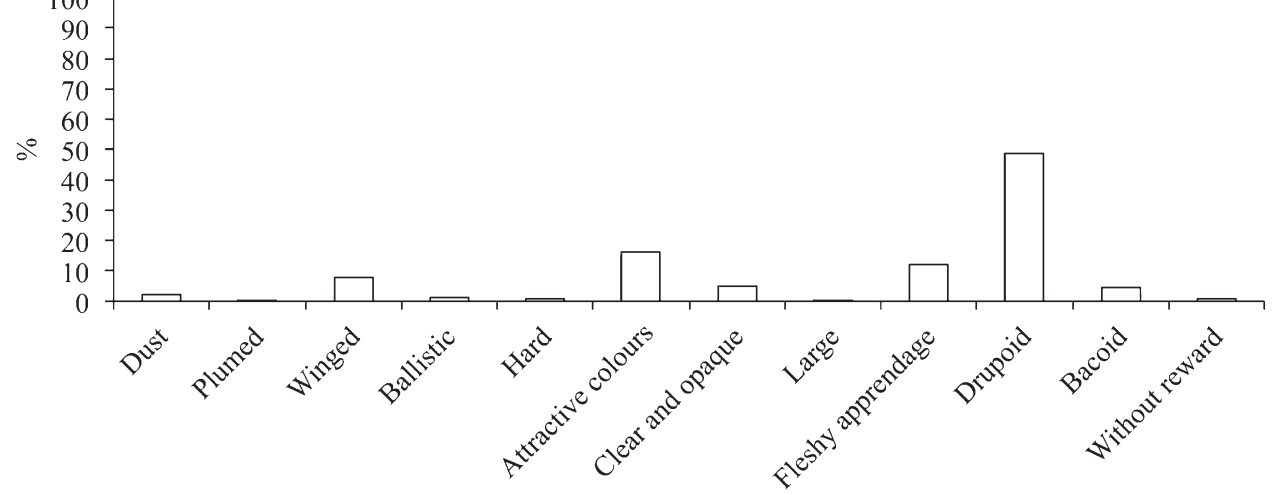

Figure 2. Dispersal spectrum within five hierarchical levels of dispersal syndromes (A-E; please see Figure 1) for the Atlantic Rainforest tree species in SE Brazil.

Most ornithochorous species found at PESM have drupoid diaspores, which are highly likely to be dispersed by large birds. The majority of mammal-dispersed species have diaspores dispersed by primates, which are large animals and can carry the diaspores distantly from the parent trees (Seidler \& Plotkin 2006). Because large animals have larger home ranges (Kelt \& Van Vuren 2001) and may carry seeds over longer distances than smaller animals (Seidler \& Plotkin 2006), the seeds and seedlings of species dispersed by them can benefit by escaping mortality due to competition, predation and pathogen infestation near the parent plant. Conversely, seeds and seedlings can also benefit from colonization of new habitats (Wang \& Smith 2002).

We found low occurrence of species dispersed by wind and the parent plant itself at PESM. Wind dispersal is predominant in regions of dry climate (van der Pijl 1972), unlike the Atlantic Rainforest. Previous studies in this type of forest also found few species dispersed by the parent plant itself (Vieira et al. 2002). Possibly, the low frequency of dispersal by wind and the parent plant itself arises from the low reproductive success of adults that release their diaspores in dense vegetation where they cannot travel long distances (Roth 1987). Additionally, the high diversity of animal dispersers at tropical forests has likely acted as a selective force driving the evolution of diaspores with characteristics attractive to animals.

This study shows that there are no differences in the dispersal spectrum among different forest types along an altitudinal range in the Atlantic Rainforest at PESM. This indicates that probably the selective pressures on dispersal syndromes resulting from climate conditions that vary within this range are not strong or counteract each other, hence resulting in the same dispersal spectrum among the forest types. The high frequency of animal-dispersed species, specifically bird-dispersed ones, contributes to the same dispersal spectrum among forest types. The high occurrence of these syndromes indicates that frugivorous animals, especially birds, are very important for the maintenance of communities in the Atlantic Rainforest unregard of altitude.

\section{Acknowledgements}

We thank Prof. MSc Jorge Tamashiro and Prof. Dr. João Semir (University of Campinas) for helping with the identification of dispersal syndromes; Prof. Dr. Simone Aparecida Vieira (University of Campinas) and other researchers of the Theme Project "Functional Gradient" for the species list of each study site; MSc Larissa Pereira (University of Campinas) for helping 
A

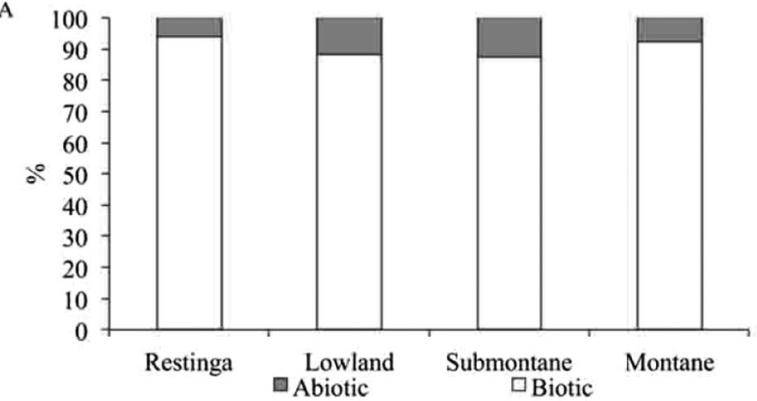

C

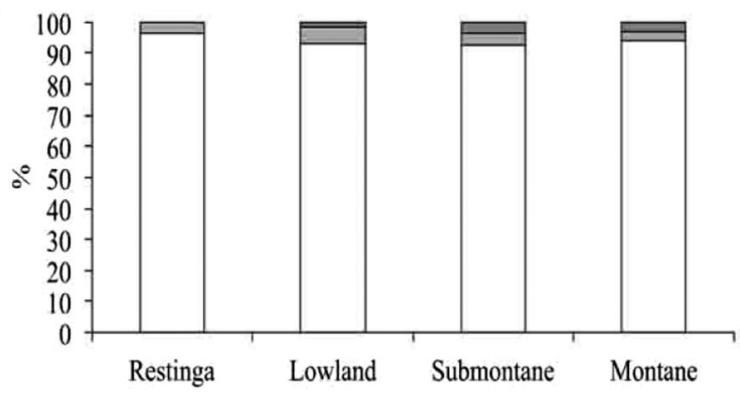

B

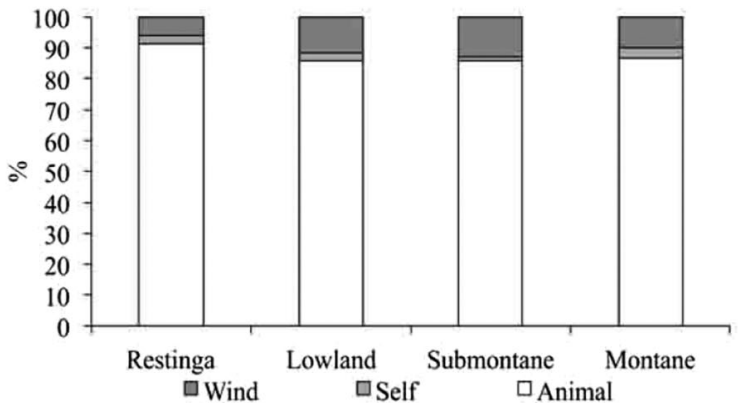

D

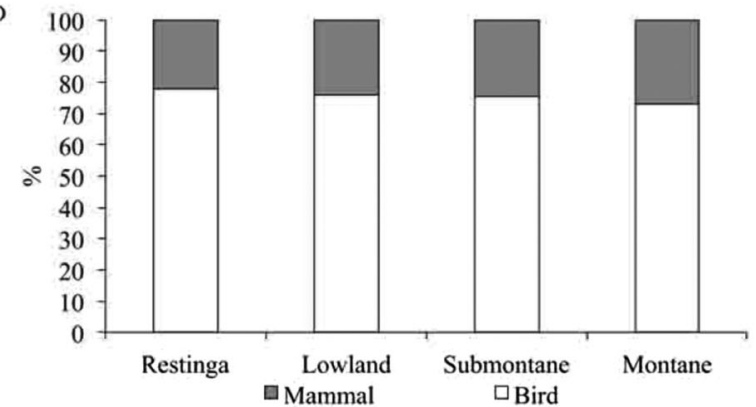

घBarochory $\square$ Autochory $\square$ Endozoochory

Figure 3. Percentage of occurrence of dispersal syndromes within four hierarchical levels (A - D; please see Figure 1) for four forest types of the Atlantic Rainforest in SE Brazil.

Table 2. Percentage of occurrence of dispersal syndromes of level 5 (please see Figure 1) for four forest types of the Atlantic Rainforest in SE Brazil. The syndromes of the immediate previous level are given for convenience.Tabela 2: Porcentagem de ocorrência das síndromes de dispersão do nível 5 (favor ver Figura 1) em quatro tipos florestais da Mata Atlântica no sudeste do Brasil. As síndromes do nível imediatamente anterior são dadas por conveniência.

\begin{tabular}{|c|c|c|c|c|c|}
\hline \multicolumn{2}{|c|}{ Dispersal syndromes } & \multicolumn{4}{|c|}{ Forest type } \\
\hline Previous level & Level 5 & Restinga & Lowland & Submontane & Montane \\
\hline \multirow[t]{4}{*}{ Bird dispersal } & Seeds with fleshy appendage attached & 14.52 & 14.02 & 12.24 & 15.41 \\
\hline & Drupospores & 47.83 & 49.93 & 49.33 & 47.56 \\
\hline & Baccaspores & 7.06 & 2.16 & 3.36 & 2.98 \\
\hline & Seeds without any nutritional reward & 2.35 & 0.00 & 0.67 & 0.00 \\
\hline \multirow[t]{4}{*}{ Mammal dispersal } & Hard diaspores & 0.00 & 0.00 & 0.67 & 1.19 \\
\hline & Diaspores with attractive colours & 12.95 & 15.97 & 16.96 & 17.54 \\
\hline & Clear and opaque diaspores & 5.88 & 3.59 & 2.68 & 6.55 \\
\hline & Large diaspores & 1.18 & 0.72 & 0.67 & 0.00 \\
\hline Autochory & Ballistic release & 2.35 & 1.44 & 0.67 & 0.60 \\
\hline \multirow{3}{*}{ Wind dispersal } & Dust diaspores & 0.00 & 2.88 & 4.03 & 1.79 \\
\hline & Plumed diaspores & 0.00 & 0.72 & 0.67 & 0.00 \\
\hline & Winged diaspores & 5.88 & 8.57 & 8.05 & 6.38 \\
\hline
\end{tabular}

with the Montane species and voucher specimens; Dr. Lívia Cordi (University of Campinas) also for helping with the voucher specimens; Ataliba Gomes (Instituto Agronômico de Campinas), Dr. Christiane Correa (University of Campinas), Dr. Cristina Baldauf (Universidade Federal Rural do Semi-Árido), Dr. Marco Mello (Universidade Federal de Minas Gerais), Prof. Dr. Paulo Oliveira and Prof. Dr. Wesley Silva (University of Campinas) for comments and suggestions; Anne Baldisseri for English translation of this manuscript; anonymous reviewers for language correction and valuable suggestions, and Programa de Pós-Graduação em Ecologia of the University of Campinas for financial support. Change the marked text for: This study was financed by Biota/FAPESP through the Theme Project Functional Gradient (03/12595-7), by CNPq through a PhD scholarship (142295/2006-0) and by FAPESP through a postdoctoral scholarship (2012/00832-0) to VFM, by CNPq through a scientific initiation scholarship (105612/2009-0) to LPDC, and by $\mathrm{CNPq}$ through a productivity fellowship (1B) to FAMS (308748/2010-7).

\section{References}

ALMEIDA-NETO, M., CAMPASSI, F., GALETTI, M., JORDANO,

P. \& OLIVEIRA-FILHO, A. 2008. Vertebrate dispersal syndromes 
along the Atlantic forest: broad-scale patterns and macroecological correlates. Global Ecol. Biogeogr. 17(4):503-513. doi: http:// dx.doi.org/10.1111/j.1466-8238.2008.00386.x

ALVES, L.F., VIEIRA, S.A., SCARANELLO, M.A., CAMARGO, P.B., SANTOS, F.A.M., JOLY, C.A. \& MARTINELLI, L.A. 2010. Forest structure and abovegroung biomass variation along an elevational gradient of tropical Atlantic moist forest (Brazil). Forest Ecol. Manag. 260 (5):679-691. doi: http://dx.doi.org/10.1016/ j.foreco.2010.05.023

BURNS, K.C., CAZETTA, E., GALETTI, M., VAlido, A. \& SCHAEFER, H.M. 2009. Geographic patterns in fruit colour diversity: do leaves constrain the colours of fleshy fruits? Oecologia 159(2):337-343. doi: http://dx.doi.org/10.1007/s00442-008-1227-3

CAMPASSI, F. 2006. Padrões geográficos das síndromes de dispersão e características dos frutos de espécies arbustivo-arbóreas em comunidades vegetais da Mata Atlântica. Tese de mestrado, Universidade de São Paulo, Escola Superior de Agricultura "Luiz de Queiroz", Piracicaba.

CARLO, T.A., COLlAZO, J.A. \& GROOM, M.J. 2003. Avian fruit preferences across a Puerto Rican forested landscape: pattern consistency and implications for seed removal. Oecologia 134(1):119-131. doi: http://dx.doi.org/10.1007/s00442-002-1087-1

DEBUSSCHE, M. \& ISENMANN, P. 1994. Bird-dispersed seed rain and seedling establishment in patchy Mediterranean vegetation. Oikos 69(3):414-426. doi: http://dx.doi.org/10.2307/3545854

EMBRAPA. http://www.bdclima.cnpm.embrapa.br. Last access in 30/ 05/2010.

FISCHER, K.E. \& CHAPMAN, C.A. 1993. Frugivores and fruit syndromes: differences in patterns at the genus and species level. Oikos 66(3):472-482. doi: http://dx.doi.org/10.2307/3544942

FUNDAÇÃO SOS MATA ATLÂNTICA. www.sosmatatlantica.org. br. Last access in 23/04/2011.

GENTRY, A.H. 1982. Patterns of neotropical plant species diversity. Evol. Biol. 15:1-84. doi: http://dx.doi.org/10.1007/978-1-4615-6968$8 \_1$

GOMIERO, L.M., SOUZA, U.P. \& BRAGA, F.M.S. 2007. Reprodução e alimentação de Rhamdia quelen (Quoy \& Gaimard, 1824) em rios do Núcleo Santa Virgínia, Parque Estadual da Serra do Mar, São Paulo, SP. Biota Neotrop. 7(3):127-133. http://www. biotaneotropica.org.br/v7n3/pt/abstract?article+bn01907032007 (last access in 23/07/2013). doi: http://dx.doi.org/10.1590/S167606032007000300015

HERRERA, C.M. 1985. Determinants of plant-animal coevolution: the case of mutualistic dispersal of seeds by vertebrates. Oikos 44(1):132-144. doi: http://dx.doi.org/10.2307/3544054

HERRERA, C.M. 1989. Frugivory and seed dispersal by carnivorous mammals, and associated fruit characteristics, in undisturbed Mediterranean habitats. Oikos 55(2):250-262. doi: http:// dx.doi.org/10.2307/3565429

HERRERA, C.M. 2002. Seed dispersal by vertebrates. In Plant-animal interactions: an evolutionary approach (C.M. Herrera \& O. Pellmry, ed). Blackwell Scientific Publications, Oxford, p.185-208.

HOLLANDER, J.L. \& VANDER WALL, S.B. 2009. Dispersal syndromes in North American Ephedra. Int. J. Plant Sci. 170(3):323-330. doi: http://dx.doi.org/10.1086/596334

HOWE, H.F., SCHUPP, E.W. \& WESTLEY, L.C. 1985. Early consequences of seed dispersal for a neotropical tree (Virola surinamensis). Ecology 66(3):781-791. doi: http://dx.doi.org/ $10.2307 / 1940539$

HUGHES, L., DUNLOP, M., FRENCH, K., LEISHMAN, M.R., RICE, B., RODGERSON, L. \& WESTOBY, M. 1994. Predicting dispersal spectra: a minimal set of hypotheses based on plant attributes. J. Ecol. 82(4):933-950. doi: http://dx.doi.org/10.2307/2261456

JANSON, C.H. 1983. Adaptation of fruit morphology to dispersal agents in a neotropical forest. Science 219(4581):187-189. doi: http://dx.doi.org/10.1126/science.219.4581.187
JANZEN, D.H. \& MARTIN, P.S. 1982. Neotropical anachronisms: the fruits the Gomphotheres ate. Science 215(4528):19-27. doi: http://dx.doi.org/10.1126/science.215.4528.19

JOLY, C.A., ASSIS, M.A., BERNACCI, L.C., TAMASHIRO, J.Y., CAMPOS, M.C.R., GOMES, J.A.M.A., LACERDA, M.S., SANTOS, F.A.M., PEDRONI, F., PEREIRA, L.S., PADGURSCHI, M.C.G., PRATA, E.M., RAMOS, E., TORRES, R.B., ROCHELlE, A., MARTINS, F.R., ALVES, L.F., VIEIRA, S.A., MARTINELLI, L.A., CAMARGO, P.B.C., AIDAR, M.P.M., EISENLOHR, P.V., SIMÕES, E., VILLANI, J.P. \& BELINELLO, R. 2012. Florística e fitossociologia em parcelas permanentes da Mata Atlântica do sudeste do Brasil ao longo de um gradiente altitudinal. Biota Neotrop. 12(1):123-145. http://www.biotaneotropica.org.br/v12n1/en/abstract?article+bn01812012012 (last access in 23/07/2013). doi: http:// dx.doi.org/10.1590/S1676-06032012000100012

KELT, D.A. \& VAN VUREN, D.H. 2001. The ecology and macroecology of mammalian home range area. Am. Nat. 157(6):637-645. doi: http://dx.doi.org/10.1086/320621

KINOSHITA, L.S., TORRES, R.B., FORNI-MARTINS, E.R., SPINELli, T., AHN, Y.J. \& CONSTÂNCIO, S.S. 2006. Composição florística e síndromes de polinização e de dispersão da mata do Sítio São Francisco, Campinas, SP, Brasil. Acta Bot. Bras. 20(2):313-327. doi: http://dx.doi.org/10.1590/S010233062006000200007

LOISELLE, B.A., RIBBENS, E. \& VARGAS, O. 1996. Spatial and temporal variation of seed rain in a Tropical Lowland Wet Forest. Biotropica 28(1):82-95. doi: http://dx.doi.org/10.2307/2388773

LOMÁSCOLO, S.B., SPERANZA, P. \& KIMBALL, R.T. 2008. Correlated evolution of fig size and color supports the dispersal syndromes hypothesis. Oecologia 156(4):783-796. doi: http:// dx.doi.org/10.1007/s00442-008-1023-0

LORD, J.M. 2004. Frugivore gape size and the evolution of fruit size and shape in southern hemisphere floras. Austral Ecol. 29(4):430436. doi: http://dx.doi.org/10.1111/j.1442-9993.2004.01382.x

MACK, A.L. 1993. The sizes of vertebrate-dispersed fruits: a neotropical-palaeotropical comparison. Am. Nat. 142(5):840-585. doi: http://dx.doi.org/10.1086/285575

MARTINI, A.M.Z. \& SANTOS, F.A.M. 2007. Effects of distinct types of disturbance on seed rain in the Atlantic forest of NE Brazil. Plant Ecol. 190(1):81-95. doi: http://dx.doi.org/10.1007/s11258-0069192-6

MARTINS, S.C. 2010. Perdas de nitrogênio pela emissão de óxido nitroso $\left(\mathrm{N}_{2} \mathrm{O}\right)$ e sua relação com a decomposição da serapilheira e biomassa de raízes na floresta de Mata Atlântica. Tese de doutorado, Universidade de São Paulo, Piracicaba.

MAZER, S.J. \& WHEELWRIGHT, N.T. 1993. Fruit size and shape: allometry at different taxonomic levels in bird-dispersed plants. Evol. Ecol. 7(6):556-575. doi: http://dx.doi.org/10.1007/ BF01237821

MCDONNELL, M.J. 1986. Old field vegetation height and the dispersal pattern of bird-disseminated woody plants. B. Torrey Bot. Club 113(1):6-11. doi: http://dx.doi.org/10.2307/2996227

MORAN, C., CATTERALL, C.P., GREEN, R.J. \& OLSEN, M.F. 2004. Functional variation among frugivorous birds: implications for rainforest seed dispersal in a fragmented subtropical landscape. Oecologia 141(4):584-595. doi: http://dx.doi.org/10.1007/s00442004-1685-1

MYERS, N., MITTERMEIER, R.A., MITTERMEIER, C.G., FONSECA, G.A.B. \& KENT, J. 2000. Biodiversity hotspots for conservation priorities. Nature 403(6772):852-858. doi: http:// dx.doi.org/10.1038/35002501

PEDRONI, F. 2001. Aspectos da estrutura e dinâmica da comunidade arbórea na Mata Atlântica de planície e encosta em Picinguaba, Ubatuba, SP. Tese de doutorado, Universidade Estadual de Campinas, Campinas. 
PHILliPS, O., BAKER, T., FELDPAUSCH, T. \& BRIENEN, R. 2009. RAINFOR field manual for plot establishment and remeasurement. http://www.rainfor.org/en/manuals. Last access in $27 / 11 / 2013$

PIZO, M.A. \& ALMEIDA-NETO, M. 2009. Determinants of fruit removal in Geonoma pauciflora, an understorey palm of neotropical forests. Ecol. Res. 24(6):1179-1186. doi: http://dx.doi.org/10.1007/ s11284-009-0599-0

RIDLEY, H.N. 1930. The dispersal of plants throughout the world. L. Reeve \& CO., LTD., Ashford.

ROTH, I. 1987. Stratification of a tropical forest as seen in dispersal types. Dr. W. Junk Publishers, Dordrecht.

SEIDLER, T. \& PLOTKIN, J.B. 2006. Seed dispersal and spatial pattern in tropical trees. PLOS Biol. 4(11):2132-2137. doi: http:// dx.doi.org/10.1371/journal.pbio.0040344

SILVA, M.C.N.A. \& RODAL, M.J.N. 2009. Padrões das síndromes de dispersão de plantas em áreas com diferentes graus de pluviosidade, PE, Brasil. Acta Bot. Bras. 23(4):1040-1047. doi: http://dx.doi.org/ 10.1590/S0102-33062009000400014

SILVA-DIAS, M.A.E., VIDALE, P.E. \& BLANCO, C.M.R. 1995. Case study and numerical simulation of the summer regional circulation in São Paulo, Brazil. Bound.-Lay. Meteorol. 74(4):371388. doi: http://dx.doi.org/10.1007/BF00712378

SOS MATA ATLÂNTICA/INPE/ISA. 1998. Atlas da evolução dos remanescentes florestais e ecossistemas associados ao domínio da Mata Atlântica no período 1990-95. SOS Mata Atlântica/INPE/ ISA, São Paulo.

SOUSA NETO, E.R. 2008. Perdas de nitrogênio pela emissão de óxido nitroso $\left(\mathrm{N}_{2} \mathrm{O}\right)$ e sua relação com a decomposição da serapilheira e biomassa de raízes na floresta de Mata Atlântica. Tese de mestrado, Universidade de São Paulo, Piracicaba.

SUGUIO, K. \& MARTIN, L. 1978. Quaternary marine formations of the states of São Paulo and southern Rio de Janeiro. In International Symposium on Coastal Evolution in the Quaternary. Universidade de São Paulo, São Paulo, p. 55.

TAKAHASHI, K. \& KAMITANI, T. 2004. Factors affecting seed rain beneath fleshy-fruited plants. Plant Ecol. 174(2):247-256. doi: http://dx.doi.org/10.1023/B:VEGE.0000049105.30878.25

VAN DER PIJL, L. 1972. Principles of dispersal in higher plants. 2 ed. Springer-Verlag, Würzburg.

VELOSO, H.P., RANGEL-FILHO, A.L.R. \& LIMA, J.C.A. 2001. Classificação da vegetação brasileira, adaptada a um sistema universal. IBGE, Rio de Janeiro.

VICENTE, A., SANTOS, A.M.M. \& TABARELLI, M. 2003. Variação no modo de dispersão de espécies lenhosas em um gradient de precipitação em em floresta seca e úmida no nordeste do Brasil. In Ecologia e conservação da caatinga (I. Leal, M. Tabarelli \& J.M.C. Silva, ed). Editora Universitária da UFPE, Recife, p.201-231.

VIEIRA, D.L.M., AQUINO, F.G., BRITO, M.A., FERNANDESBULHÃO, C. \& HENRIQUES, R.P.B. 2002. Síndromes de dispersão de espécies arbustivo-arbóreas em cerrado sensu stricto do Brasil Central e savanas amazônicas. Rev. Bras. Bot. 25(2):215220. doi: http://dx.doi.org/10.1590/S0100-84042002000200009

WANG, B.C. \& SMITH, T.B. 2002. Closing the seed dispersal loop. Trends Ecol. Evol. 17(8):379-385. doi: http://dx.doi.org/10.1016/ S0169-5347(02)02541-7

WHEELWRIGHT, N.T. 1985. Fruit size, gape width, and the diets of fruit-eating birds. Ecology 66(3):808-818. doi: http://dx.doi.org/ $10.2307 / 1940542$

WILLSON, M.F., IRVINE, A.K. \& WALSH, N.G. 1989. Vertebrate dispersal syndromes in some Australian and New Zealand plant communities, with geographic comparisons. Biotropica 21(2):133147. doi: http://dx.doi.org/10.2307/2388704

WILLSON, M.F., RICE, B.L. \& WESTOBY, M. 1990. Seed dispersal spectra: a comparison of temperate plant communities. J. Veg. Sci. 1(4):547-562. doi: http://dx.doi.org/10.2307/3235789

ZAR, J.H. 1999. Biostatistical analysis. 4 ed. Prentice-Hall, Upper Saddle River.

\section{Supplementary material 1: Protocol for the classifi- cation of dispersal syndromes}

This protocol includes a description of diaspore and vegetative characteristics that will help to identify all forms of diaspore dispersal. The exception are the following forms that are absent from tree species or that do not present common traits that indicate a dispersal syndrome: (1) dispersal by slugs, which does not constitute a dispersal syndrome (Gervais et al. 1998, Tuerke et al. 2010); (2) dispersal by earthworms, which also does not constitute a dispersal syndrome (Milcu et al. 2006); (3) dispersal by bees, described for only two tree species with fruits that produce resin or wax (Wallace \& Trueman 1995, Wallace et al. 2008); (4) dispersal by beetles, mainly described for dung beetles, which collect faeces containing seeds primarily dispersed by vertebrates (Vulinec 2002). However, beetles have also been found ingesting fruit pulp with seeds of one parasitic species in the Mediterranean region (de Vega et al. 2011); (5) dispersal by weta, giant flightless crickets in New Zealand (Burns 2006, Duthie et al. 2006); (6) ant-dispersed species that form ant gardens and only occur in epiphytes (Ule 1905 apud van der Pijl 1972, van der Pijl 1972); (7) ant-dispersed species with short stems that droop to the ground when the seeds are ripe, which can only occur in herbaceous plants (Handel \& Beattie 1990); (8) dispersal by tree-frogs, found only in a single bromeliad species (Silva et al. 1989); (9) woody or dry fruits with small hard seeds produced by herbaceous plants; (10) tumbleweeds, restricted to herbaceous plants, and (11) diaspores that submerge in water, which only occur in aquatic species (van der Pijl 1972). The main studies reviewed for the elaboration of this protocol were: Ridley (1930), van der Pijl (1972), Roth (1987), Herrera (1989), Banack (1998), Laubhann $\&$ Puff (2002) and Dumont (2003). All characteristics described here can be observed in herbarium specimens, photographs, diagrams and information about the species in the literature.

The protocol is organized into hierarchical levels, according to the diagram in Fig. 1 presented in the paper. The diagram establishes a hierarchical classification of the dispersal syndromes in five levels, each composed of several groups. At each subsequent level of the hierarchy, the morphological characteristics of the diaspores are given in greater detail, thus further specifying the disperser agents. As a result, the characteristics of the syndromes become more specific from the upper levels to the lower levels. Nevertheless, some dispersal syndromes are unfiled to all hierarchical levels. This happens because some diaspores reach a high level of detail without showing intermediate levels and, thus, are classified directly into level 5 of the hierarchy.

A list of all tree species sampled at four forest types of the Atlantic Rainforest in Southeast Brazil and their dispersal syndromes belonging to the five hierarchical levels proposed herein can be found at supplementary material 2. In this protocol, we only give examples of species with dispersal syndromes that were not found at the study site.

\section{Level 1: Dispersal by biotic agents}

1.1. Level 2: Animal dispersal: animal-dispersed diaspores can either be consumed or stick externally to the body of animals (Ridley 1930, van der Pijl 1972).

1.1.1. Level 3: Endozoochory (diaspores consumed by animals): endozoochorous diaspores usually contain a fleshy 
portion, such as fruits with pulp and seeds with fleshy appendages attached. This fleshy portion primarily provides nutrients and energy to the animals (Ridley 1930, van der Pijl 1972, Hölldobler \& Wilson 1990). The diaspores can present odour, attractive colours (bright yellow, orange, red, pink, purple, blue or black) and protection against premature consumption, such as green colour and unpalatable substances (van der Pijl 1972). The fruits may have hard or soft skin (Banack 1998, Dumont 2003), and a sweet flavour because, when ripe, their sugar content increases. Moreover, they become softer due to the presence of pectin (Raven 2007).

1.1.1.1. Level 4: Ant dispersal: the characteristic diagnosing this syndrome are seeds covered by an oleaginous external portion, which generally makes up the elaiosome. The lipid compounds are volatile and attract ants, which carry the seeds to their nest to feed on the oleaginous portion, eventually dispersing the seeds (Ridley 1930, van der Pijl 1972, Hölldobler \& Wilson 1990). The groups of ant dispersal presented below are intended only to facilitate the identification of diaspores dispersed by ants and are not an actual level within the syndrome. One example of species dispersed by ants is Mabea fistulifera Mart.

i- Seeds with elaiosome attached: are characterized by the presence of a fleshy appendage externally to the seed. It is rich in lipids and is called the elaiosome (van der Pijl 1972, Hölldobler \& Wilson 1990). It is usually white, contrasting with the seed, which is dark, hard, smooth and apparently difficult to destroy (van der Pijl 1972). One example of species that produce seeds with an elaiosome attached is Mabea fistulifera.

ii- Seeds that secrete lipids by the testa: are characterized by the presence of an oleaginous material distributed throughout the whole fleshy testa. Sometimes, this material can be found in small parts of the inflorescence that remain attached to the seeds (Ridley 1930, van der Pijl 1972). Species of Ficus secrete lipids by the testa, but we classified the five species of this genus found in the forest types studied as mammal-dispersed, with clear and opaque diaspores (correspondent to those attractive to bats; item 1.1.1.5.3.) because they presented more characteristics of this syndrome than of ant dispersal.

When the seed has no elaiosome attached or oleaginous material distributed throughout its fleshy testa, characteristics of the parent plant may indicate the occurrence of dispersal by ants. In this case, the plants can facilitate the encounter of the diaspores by ants, and also provide food and/or shelter for them. Therefore, while foraging on the plant, the ants find the diaspores and take them to their nests (Ridley 1930, van der Pijl 1972, Handel \& Beattie 1990). The characteristics of the parent plants indicating the occurrence of dispersal by ants are:

iii- Form of diaspore presentation: dehiscent fruits (open spontaneously during maturation) that remain open for a long time and infructescences with seeds that are easily accessible (Handel \& Beattie 1990, Gonçalves \& Lorenzi 2007). A herbaceous species with the latter form of presentation of its diaspores is Urera baccifera (L.) Gaudich. ex Wedd.

iv- Plants with extra-floral nectaries (EFNs) or post-floral nectaries (PFNs): nectaries are glands that produce nectar, a secretion rich in sugars. EFNs are usually located on the stem, the petiole or the leaf blade (van der Pijl 1972, Hölldobler \& Wilson 1990, Gonçalves \& Lorenzi 2007). The PFNs are located next to the fruits and secrete nectar even during fruit development (van der Pijl 1972, Ferri et al. 1981). One example of species with EFNs is Acacia pycnantha Benth. v- Plants with formicaries: formicaries are spaces in the leaf or on the stem that serve as shelter for ants (Hölldobler \& Wilson 1990). A herbaceous species with formicaries is Tococa formicaria Mart..

vi- Plants with food bodies: food bodies are small, pearl-like epidermal structures, showing basal constriction. Lipids and glycogen are the major metabolites of these structures, which may be associated with EFNs and formicaries. The food bodies are located in different parts of the plant, such as in the rachis (main vein of compound leaves) and pinnule (last leaflets of leaves with blades divided close to the main vein), or at the base of the petiole (Ferri et al. 1981, Gonçalves \& Lorenzi 2007). One example of species that have food bodies are those belonging to Acacia.

1.1.1.2. Level 4: Fish dispersal: occurs in species that grow on riverbanks or in flooded sites. Their diaspores are heavy and fall off the parent plant into the water where they may either sink or float. These diaspores may have hard skin, which can only be opened by the jaws of fish, and many small, hard seeds, which are not damaged during the passage through the digestive tract (van der Pijl 1972, Kubitzki \& Ziburski 1994). One example of species dispersed by fish is Eugenia inundata DC.

1.1.1.3. Level 4: Reptile dispersal (performed by lizards, alligators and turtles): is characterized by fruits equipped with odour (van der Pijl 1972), usually with a red or orange colour (Klimstra \& Newsome 1960), and that develop close to the ground or fall off from the parent plant when ripe. Some species have fruits equipped with hard skin (van der Pijl 1972). One example of species dispersed by reptiles is Celtis australis L.

1.1.1.4. Level 4: Bird dispersal: diaspores dispersed by birds are bright and show contrasting colours, such as red and black, orange and black, and black or dark blue with light colours; contrast between the diaspores and leaves; contrast between the diaspores and its coloured auxiliary organs. The diaspores usually have an edible part, such as the fruit pulp or fleshy appendages attached to the seed. However, there are some birddispersed seeds that do not have an edible part, although their colour is attractive to birds and resembles seeds with fleshy appendages or fleshy fruits. These seeds are commonly referred to as mimetic (van der Pijl 1972, Laubhann \& Puff 2002), although there are other hypotheses for the evolution of such colour pattern (see Peres \& van Rossmalen 1996, Foster \& Delay 1998 and Galetti 2002). When immature, bird-dispersed diaspores have an external protection against premature consumption; the seeds also have a protection from premature digestion (van der Pijl 1972). The diaspores are easily accessible to birds, such as hanging fruit and/or seeds (van der Pijl 1972, Roth 1987), rarely have an odour (van der Pijl 1972) and are small ( $\leq 2 \mathrm{~cm}$; Willson et al. 1989). Due to the great variation of bird-dispersed diaspores, they can be classified according to their morphology into the following groups:

1.1.1.4.1. Level 5: Seeds with fleshy appendage attached: are characterized by seeds fully or partially covered by sarcotesta, aril or ariloid structures (Barroso et al. 1999). These appendages provide a contrasting colour with the seed. The seeds are exposed in hard-skinned dehiscent fruits (van der Pijl 1972, Laubhann \& Puff 2002).

1.1.1.4.2. Level 5: Drupoid diaspores: are characterized by diaspores with a single or just a few seeds (the species analysed showed up to six), which are large in relation to the diaspore. The exocarp, or skin of the fruit or fruitlet, has attractive 
colours to birds and is not rigid. Drupoid diaspores are indehiscent (do not open during maturation; Gonçalves \& Lorenzi 2007). During the dispersal event, mainly large-bodied birds can swallow the whole diaspore and carry its large seeds (Wheelwright 1985). Small birds can sometimes swallow diaspores with a single or just a few large seeds, but they are less willing or able to carry the mass of ballast associated with them (Mack 1993). Therefore, small birds are most likely to only peck at the pulp of drupoid diaspores and do not act as dispersers of their large seeds.

1.1.1.4.3. Level 5: Baccoid diaspores: are characterized by diaspores with dozens or hundreds of small seeds immersed in the pulp. The exocarp has attractive colours to birds and is not rigid. Baccoid diaspores are indehiscent. During the dispersal event, a bird carries several seeds belonging to the same baccoid diaspore: the number of seeds varies with the size of the bird in relation to the size of the diaspore, which may be swallowed whole or have a portion pecked at. The terms drupoid and baccoid diaspores were here employed because, even though there are classifications for fruits in the literature, there are no specific terms for diaspores (either a single fruit, or a fruitlet from a compound fruit or infructescence) with these characteristics.

1.1.1.4.4. Level 5: Seeds without any nutritional reward: are characterized by seeds with colours similar to that of seeds with a fleshy appendage so that they appear to have one. Seeds without nutritional reward may also appear to be juicy, similar to a fleshy fruit. However, they are hard and dry (van der Pijl 1972, Laubhann \& Puff 2002).

1.1.1.5. Level 4: Mammal dispersal: the diaspores are usually large ( $>2 \mathrm{~cm}$; Ridley 1930, van der Pij1 1972) and the seeds are protected from premature digestion. Some fruits have an external protection against premature consumption, while the edible portion in others has a green colour even when ripe. The ripe fruits may have a strong odour, which is typical of diaspores dispersed by mammals (van der Pijl 1972). Mammaldispersed fruits have a watery pulp (van der Pijl 1972, Albuquerque 2001) and hard or soft skin (Banack 1998, Dumont 2003), lie outside the foliage attached to the stem or near the ground, and fall off the parent plant continuously. Attractive colours are not always present (van der Pijl 1972). Mammals can also disperse dry fruits, or consume large seeds with yellow or orange fleshy appendages. Due to the great variation of mammal-dispersed diaspores, they can be classified according to their morphology into the following groups:

1.1.1.5.1. Level 5: Hard diaspores (attractive to rodents): are often equipped with a hard exocarp (van der Pijl 1972), green pericarp and one or more seeds (Ridley 1930). The typical odour found in mammal-dispersed fruits is absent (van der Pijl 1972). Some fruits belonging to this group are fleshy, made up of red, green or yellow capsules, with seeds surrounded by a white pulp (Ridley 1930). Seeds with hard, waxy ariloid structures attached also belong to this group (van der Pijl 1972).

1.1.1.5.2. Level 5: Diaspores with attractive colours (attractive to primates): are characterized by the most coloured fruits amongst those dispersed by mammals (van der Pijl 1972), with black, purple, pink, yellow, orange or grey-green colours (Ridley 1930). The fruits belonging to this group may have hard or soft skin, a strong odour (but not a rotten smell) and juiciness (van der Pij1 1972). Seeds with a yellow or orange aril (Ridley 1930, van der Pijl 1972), much larger than those dispersed by birds, also belong to this group (Ridley 1930).
1.1.1.5.3. Level 5: Clear and opaque diaspores (attractive to bats): are characterized by clear and opaque colours (van der Pijl 1972), in shades of purple, blue, green, yellow, yellowgreen, white or orange. They contrast with the darker foliage and make the diaspores more easily seen at night by bats (Dumont 2003). Clear and opaque diaspores are unprotected and exposed on branches, generally have a watery pulp (van der Pijl 1972, Albuquerque 2001) and may be equipped with hard or soft skin (Banack 1998, Dumont 2003). They often have a strong odour, conferred by aromatic compounds; the odour is not necessarily a rotten smell and may be imperceptible to humans. The fruit shape is highly variable and may be spherical to cob-shaped (M.A.R. Mello personal communication). The fruits are of different sizes (Dumont 2003) and occur mainly in the families Araceae, Clusiaceae, Cucurbitaceae, Moraceae, Piperaceae, Solanaceae and Urticaceae (van der Pijl 1972, Mello et al. 2008).

1.1.1.5.4. Level 5: Large diaspores (attractive to mammals belonging to the order Carnivora): are characterized by fruits that are much heavier $(2.23 \mathrm{~g} \pm 4.05 \mathrm{~g})$ than those dispersed by birds and other mammals (with the exception of diaspores with attractive colours and anachronistic fruits), rich in pulp (68.9\% $\pm 18.6 \%$ of fresh fruit mass) and with many seeds (60 \pm 258 seeds/fruit; Herrera 1989). They also have a specific odour and commonly fall off the parent plant when ripe. Their colours are attractive, such as red, black, and mainly brown, white, blue and green (Ridley 1930, Herrera 1989). The fruits of this group generally belong to herbaceous plants and to species of Arecaceae (Ridley 1930, van der Pijl 1972).

1.1.1.5.5. Level 5: Anachronistic fruits: are characterized by very large, indehiscent fruits (much larger than those belonging to the other syndromes) with a pulp rich in oil, sugar or nitrogen compounds. They lack any attractive colour. The hardness, size and weight of these fruits are similar to those consumed by large African mammals. These features indicate that the anachronistic fruits were dispersed by the South American megafauna, which became extinct about 10,000 years ago. After the extinction of these animals, there might have been a population decline of the plant species dispersed by them, although some would still remain viable due to sporadic dispersal by other agents (Janzen \& Martin 1982, Guimarães Jr. et al. 2008). Other characteristics of anachronistic fruits are the presence of seeds enclosed within a hard or thick endocarp, or soft or fragile seeds that are very small or embedded in a hard portion of the fruit (Janzen \& Martin 1982). Examples of species of this group are: Crescentia alata Kunth, Enterolobium cyclocarpum (Jacq.) Griseb. and Hippomane mancinella L.

1.1.2. Level 3: Epizoochory (or exozoochory; diaspores that cling externally to the body of animals): the diaspores do not have an edible portion and therefore do not provide resources for animals. They also do not have attractive colours and odour, and have a rough texture (Sorensen 1986) and adhering mechanisms such as thorns, barbs, hairs (usually hard and curved), hooks or sticky exudates (van der Pijl 1972, Sorensen 1986, Raven 2007) which allow the diaspores to stick to animal scales, feathers and fur. The diaspores may be dry fruits that are easily detached from the parent plant when ripe. They develop near the ground and occur mainly in herbaceous species (Ridley 1930, van der Pijl 1972). Examples of herbaceous epizoochorous species are: Acanthospermum hispidum DC., Bidens laevis (L.) B.S.P. and Desmodium psilophyllum Schlecht.; we did not find any example of a tree species with this syndrome. 
1.2. Level 2: Self dispersal (dispersal performed by the parent plant itself):

1.2.1. Level 3: Autochory (dispersal performed actively by the parent plant): is characterized by diaspores with brown or pale colours (Roth 1987). Autochorous diaspores can be released from the parent plant in two ways:

1.2.1.1. Level 5: Explosive or ballistic release: is characterized by seeds and fruits with structures or mechanisms (turgor and hygroscopic movements) that shoot the diaspores away from the parent plant. They are usually dry fruits (van der Pijl 1972, Albuquerque 2001).

1.2.1.2. Level 5: Blastochory: is characterized by the growth of branches with fruits at the tip, causing the seeds to fall further away from the parent plant (van der Pijl 1972). Examples of herbaceous species of this group are: Aegilops ovata L. and Erodium ciconium (L.) L'Hér.; we did not find any example of a tree species with blastochorous diaspores.

1.2.2. Level 3: Barochory (fall of the diaspores because of gravity): is characterized by diaspores with aerodynamic shapes such as a round one, and a relatively large mass (van der Pijl 1972). Some barochorous species have dry fruits (such as capsules that open at the sept; Gonçalves \& Lorenzi 2007), from which the seeds are detached (Albuquerque 2001).

\section{Level 1: Dispersal by abiotic agents}

2.1. Level 2: Wind dispersal: is characterized by dry fruits without attractive colours, which is often brown. The fruits are equipped with numerous seeds of generally small mass (van der Pij1 1972). Wind-dispersed diaspores can be classified according to their morphological characteristics into the following groups:

2.1.1. Level 5: Dust diaspores: are characterized by very small and light weighted seeds (about $10^{-6} \mathrm{~g}$; van der Pijl 1972).

2.1.2. Level 5: Balloons: are characterized by small seeds with testa in the shape of a balloon, or balloon-shaped fruits such as inflated and indehiscent pods. Sometimes this shape is provided by an auxiliary organ such as a bracteole or the perianth (van der Pijl 1972). One example of species of this group is Colutea arborescens L.

2.1.3. Level 5: Plumed diaspores: have hairs originated from different structures. The hairs can be long (single or more than one) or occur in tufts (van der Pijl 1972). Some plumed seeds are encased in a capsule or pod and the hairs expand externally to the fruit. These hairs can be thin, simple, straight and silky; branched or tangled; or form a woolly mass (Ridley 1930). The diaspores belonging to this group have well-developed, smooth, silky hairs, different from the hard ones of epizoochorous diaspores (Sorensen 1986).

2.1.4. Level 5: Winged diaspores: are characterized by one or more flattened protrusions called wings, which may originate from the seed, the fruit or auxiliary organs (van der Pijl 1972).

2.1.5. Level 5: Wind-ballists (anemoballists): are characterized by diaspores that are released explosively after a gust of wind. They are heavier than wind-dispersed diaspores belonging to the other groups (van der Pijl 1972). One herbaceous species of this group is Papaver somniferum L.; we did not find any example of a tree species dispersed ballistically by wind.

2.2. Level 2: Water dispersal: occurs mainly in plants from aquatic environments (Ridley 1930, van der Pij1 1972), but has also been described for a herbaceous species in the Atlantic Rainforest (Pizo \& Morellato 2002). The diaspores can often float, at least for short distances, and are heavier than those dispersed by wind (Ridley 1930, van der Pijl 1972). One example of a species dispersed by water is Cocos nucifera L. Water-dispersed diaspores can be classified according to their morphological characteristics into the following groups:

2.2.1. Level 5: Rain wash (ombrohydrochory): is characterized by brown coloured dry fruits equipped with numerous seeds, as in some wind-dispersed diaspores. However, they are heavier than the latter (van der Pijl 1972). Examples of herbaceous species of this group are: Geigeria acaulis (Sch. Bip.) Benth \& Hook. Ex Oliv. \& Hiern., Leptaleum filifolium (Willd.) DC. and Sedum acre L.; we did not find any example of a tree species with rain wash dispersal.

2.2.2. Level 5: Rain-ballists: are characterized by seeds that are released explosively from the fruit driven by rainfall. The seeds are released from cup-shaped fruits, by a catapult mechanism of the fruit or through fruit pores (van der Pijl 1972, Pizo \& Morellato 2002). The latter was described for Bertolonia mosenii Cogn. (Melastomataceae), a perennial herb of the Atlantic Rainforest: the rainfall squeezes the seeds out of the triangular capsule-fruit through pores present at its vertices (known as the squirt-corner mechanism). The seeds are obovate (oval-shaped, with a wider part toward the apex of the seed) and cleaved (club-shaped, with a dilated portion on the extremities; Ferri et al. 1981, Pizo \& Morellato 2002), contrasting with the seeds released from cup-shaped fruits, which are lenticular (lensshaped; Pizo \& Morellato 2002). Examples of herbaceous species of this group are: Bertolonia mosenii, Ocimum basilucum L. and Thlaspi perfoliatum L.; we did not find any example of a tree species dispersed ballistically by rain.

2.2.3. Level 5: Floating diaspores: are generally seeds that have both a waterproof testa and low density, which is possible due to the presence of aerenchyma, light albumen and cotyledons, or corky tissues (van der Pijl 1972). Examples of species of this group are: Cocos nucifera and Hevea brasiliensis (Willd. ex Adr. de Juss.) Muell-Arg.

Diaspores without specific morphological characteristics: are characterized by the absence of morphological features that allow us to identify the syndrome to which they belong.

\section{References}

ALBUQUERQUE, L.B. 2001. Polinização e dispersão de sementes em Solanáceas Neotropicais. Tese de doutorado, Universidade Estadual de Campinas, Campinas.

BANACK, S.A. 1998. Diet selection and resource use by flying foxes (genus Pteropus). Ecology 79(6):1949-1967. doi: http://dx.doi.org/ 10.1890/0012-9658(1998)079[1949:DSARUB]2.0.CO;2

BARROSO, G.M., MORIM, M.P., PEIXOTO, A.L. \& ICHASO, C.L.F. 1999. Frutos e sementes, morfologia aplicada à sistemática de dicotiledôneas. Editora da Universidade Federal de Viçosa, Viçosa.

BURNS, K.C. 2006. Weta and the evolution of fleshy fruits in New Zealand. New Zeal. J. Ecol. 30(3):405-406.

DE VEGA, C, ARISTA, M., ORTIZ, P.L., HERRERA, C. M. \& TALAVERA, S. 2011. Endozoochory by beetles: a novel seed dispersal mechanism. Ann. Bot. 107(4):629-637. doi: http:// dx.doi.org/10.1093/aob/mcr013

DUMONT, E. 2003. Bats and fruits: an ecomorphological approach. In Bat ecology (T.H. Kunz \& M.B. Fenton, ed). The University of Chicago Press, Chicago, p.398-429.

DUTHIE, C., GIBBS, G. \& BURNS, K.C. 2006. Seed dispersal by weta. Science 311(5767):1575. doi: http://dx.doi.org/10.1126/ science. 1123544 
FERRI, M.G., MENEZES, N.L. \& MONTEIRO, W.R. 1981. Glossário ilustrado de botânica. Nobel, São Paulo.

FOSTER, M.S. \& DELAY, L.S. 1998. Dispersal of mimetic seeds of three species of Ormosia (Leguminosae). J. Trop. Ecol. 14(4):389411. doi: http://dx.doi.org/10.1017/S0266467498000303

GALETTI, M. 2002. Seed dispersal of mimetic fruits: parasitism, mutualism, aposematism or exaptation? In Seed dispersal and frugivory: ecology, evolution and conservation (D.J. Levey, W.R. Silva \& Galetti, M., ed). CABI Publishing, Cambridge, p.177-191.

GERVAIS, J.A., TRAVESET, A. \& WILLSON, M.F. 1998. The potential of seed dispersal by the Banana Slug (Ariolimax columbianus). Am. Midl. Nat. 140(1):103-110. doi: http:// dx.doi.org/10.1674/0003-0031(1998)140[0103:TPFSDB]2.0.CO;2

GONÇALVES, E.G. \& LORENZI, H. 2007. Morfologia vegetal: organografia e dicionário ilustrado de morfologia das plantas vasculares. Instituto Plantarum de Estudos da Flora, Nova Odessa.

GUIMARÃES JR., P.R.; GALETTI, M. \& JORDANO, P. 2008. Seed dispersal anachronisms: rethinking the fruits extinct megafauna ate. PLOS One 3(3):e1745. doi: http://dx.doi.org/10.1371/journal.pone. 0001745

HANDEL, S.N. \& BEATTIE, A.J. 1990. Seed dispersal by ants. Sci. Am. 263(2):76-83. doi: http://dx.doi.org/10.1038/scientificamerican0890-76

HERRERA, C.M. 1989. Frugivory and seed dispersal by carnivorous mammals, and associated fruit characteristics, in undisturbed Mediterranean habitats. Oikos 55(2):250-262. doi: http:// dx.doi.org/10.2307/3565429

HÖLLDOBLER, B. \& WILSON, E.O. 1990. The ants. The Belknap Press, Cambridge.

JANZEN, D.H. \& MARTIN, P.S. 1982. Neotropical anachronisms: the fruits the Gomphotheres ate. Science 215(4528):19-27. doi: http://dx.doi.org/10.1126/science.215.4528.19

KLIMSTRA, W.D. \& NEWSOME, F. 1960. Some observations on the food coactions of the common Box Turtle (Terrapene c. caroline). Ecology 41(4):639-647. doi: http://dx.doi.org/10.2307/1931795

KUBITZKI, K. \& ZIBURSKI, A. 1994. Seed dispersal in flood plain forest of Amazonia. Biotropica 26(1):30-43. doi: http://dx.doi.org/ $10.2307 / 2389108$

LAUBHANN, D. \& PUFF, C. 2002. Birds and bird colors - Flowers pollinated by birds; diaspores dispersed by birds. Examples from the flora of Thailand. Botanical Student Field Trip to Thailand February/March:153-170.

MACK, A.L. 1993. The sizes of vertebrate-dispersed fruits: a neotropical-palaeotropical comparison. Am. Nat. 142(5):840-585. doi: http://dx.doi.org/10.1086/285575

MELLO, M.A.R., KALKO, E.K.V. \& SILVA, W.R. 2008. Diet and abundance of the bat Sturnira lilium (Chiroptera) in a Brazilian Montane Atlantic Forest. J. Mammal. 89(2):485-492. doi: http:// dx.doi.org/10.1644/06-MAMM-A-411R.1
MILCU, A., SCHUMACHER, J. \& SCHEU, S. 2006. Earthworms (Lumbricus terrestris) affect plant seedling recruitment and microhabitat heterogeneity. Funct. Ecol. 20(2):261-268. doi: http:// dx.doi.org/10.1111/j.1365-2435.2006.01098.x

PERES, C.A. \& VAN ROSSMALEN, M.G.M. 1996. Avian dispersal of mimetic seeds of Ormosia lignivalvis by terrestrial granivores: deception or mutualism? Oikos 75(2):249-258. doi: http:// dx.doi.org/10.2307/3546248

PIZO, M.A. \& MORELLATO, L.P.C. 2002. A new rain-operated seed dispersal mechanism in Bertolonia mosenii (Melastomataceae), a Neotropical rainforest herb. Am. J. Bot. 89(1):169-171. doi: http:// dx.doi.org/10.3732/ajb.89.1.169

RAVEN, P.H., EVERT, R.F. \& EICHHORN, S.E. 2007. Biologia vegetal. 7 ed. Editora Guanabara Koogan, Rio de Janeiro.

RIDLEY, H.N. 1930. The dispersal of plants throughout the world. L. Reeve \& CO., LTD., Ashford.

ROTH, I. 1987. Stratification of a tropical forest as seen in dispersal types. Dr. W. Junk Publishers, Dordrecht.

SILVA, H.R., BRITO-PEREIRA, M.C. \& CARAMASCHI, U. 1989. Frugivory and seed dispersal by Hyla truncata, a neotropical treefrog. Copeia 1989(3):781-783. doi: http://dx.doi.org/10.2307/1445517

SORENSEN, A.E. 1986. Seed dispersal by adhesion. Annu. Rev. Ecol. Syst. 17(1):443-463. doi: http://dx.doi.org/10.1146/annurev.es.17.110186.002303

TUERKE, M., HEINZE, E., ANDREAS, K., SVENDSEN, S.M., GOSSNER, M.M. \& WEISSER, W.W. 2010. Seed consumption and dispersal of ant-dispersed plants by slugs. Oecologia 163(3):681-693. doi: http://dx.doi.org/10.1007/s00442-010-1612-6

VAN DER PIJL, L. 1972. Principles of dispersal in higher plants. 2 ed. Springer-Verlag, Würzburg.

VULINEC, K. 2002. Dung beetle communities and seed dispersal in primary forest and disturbed land in Amazonia. Biotropica 34(2):297-309. doi: http://dx.doi.org/10.1111/j.17447429.2002.tb00541.x

WALLACE, H.M. \& TRUEMAN, S.J. 1995. Dispersal of Eucalyptus torelliana seeds by the resin-collecting stingless bee, Trigona carbonaria. Oecologia 104(1):12-16. doi: http://dx.doi.org/10.1007/ BF00365556

WALLACE, H.M., HOWELL, M.G. \& LEE, D.J. 2008. Standard yet unusual mechanisms of long-distance dispersal: seed dispersal of Corymbia torelliana by bees. Divers. Distrib. 14(1):87-94. doi: http://dx.doi.org/10.1111/j.1472-4642.2007.00427.x

WHEELWRIGHT, N.T. 1985. Fruit size, gape width, and the diets of fruit-eating birds. Ecology 66(3):808-818. doi: http://dx.doi.org/ $10.2307 / 1940542$

WILLSON, M.F., IRVINE, A.K. \& WALSH, N.G. 1989. Vertebrate dispersal syndromes in some Australian and New Zealand plant communities, with geographic comparisons. Biotropica 21(2):133147. doi: http://dx.doi.org/10.2307/2388704

Received: 23/07/2013

Revised: 07/01/2014

Accpeted: 26/03/2014 


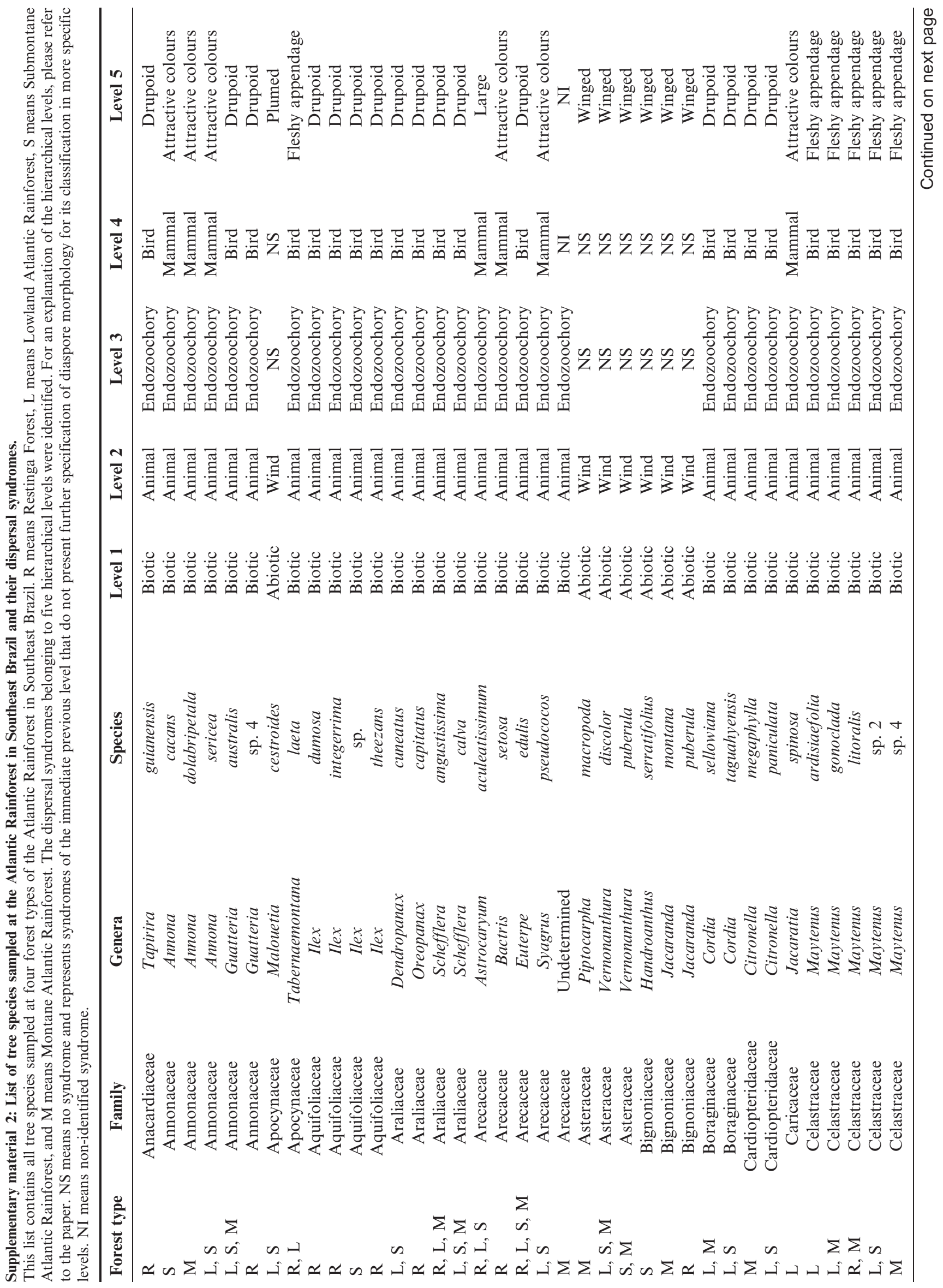




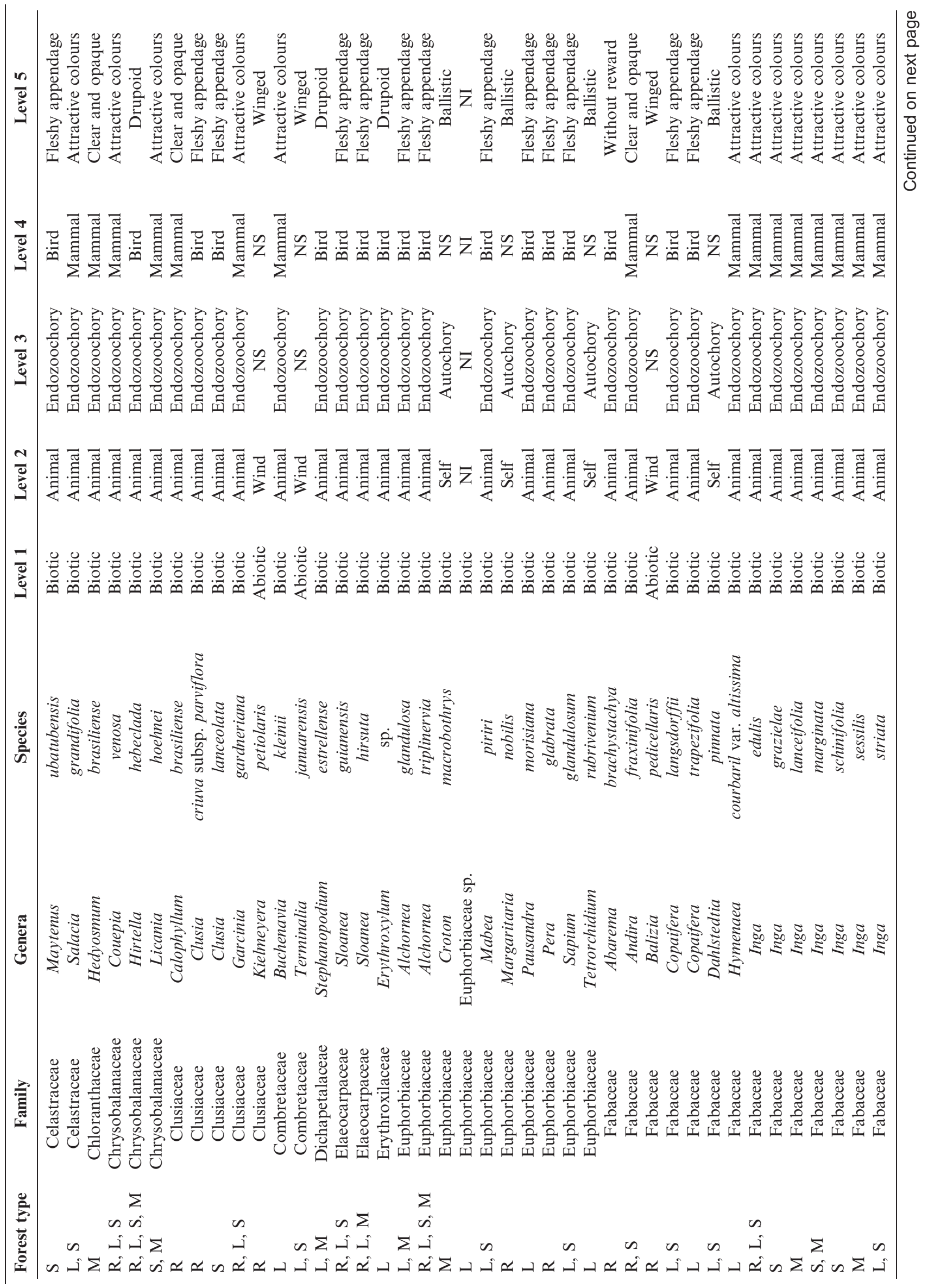




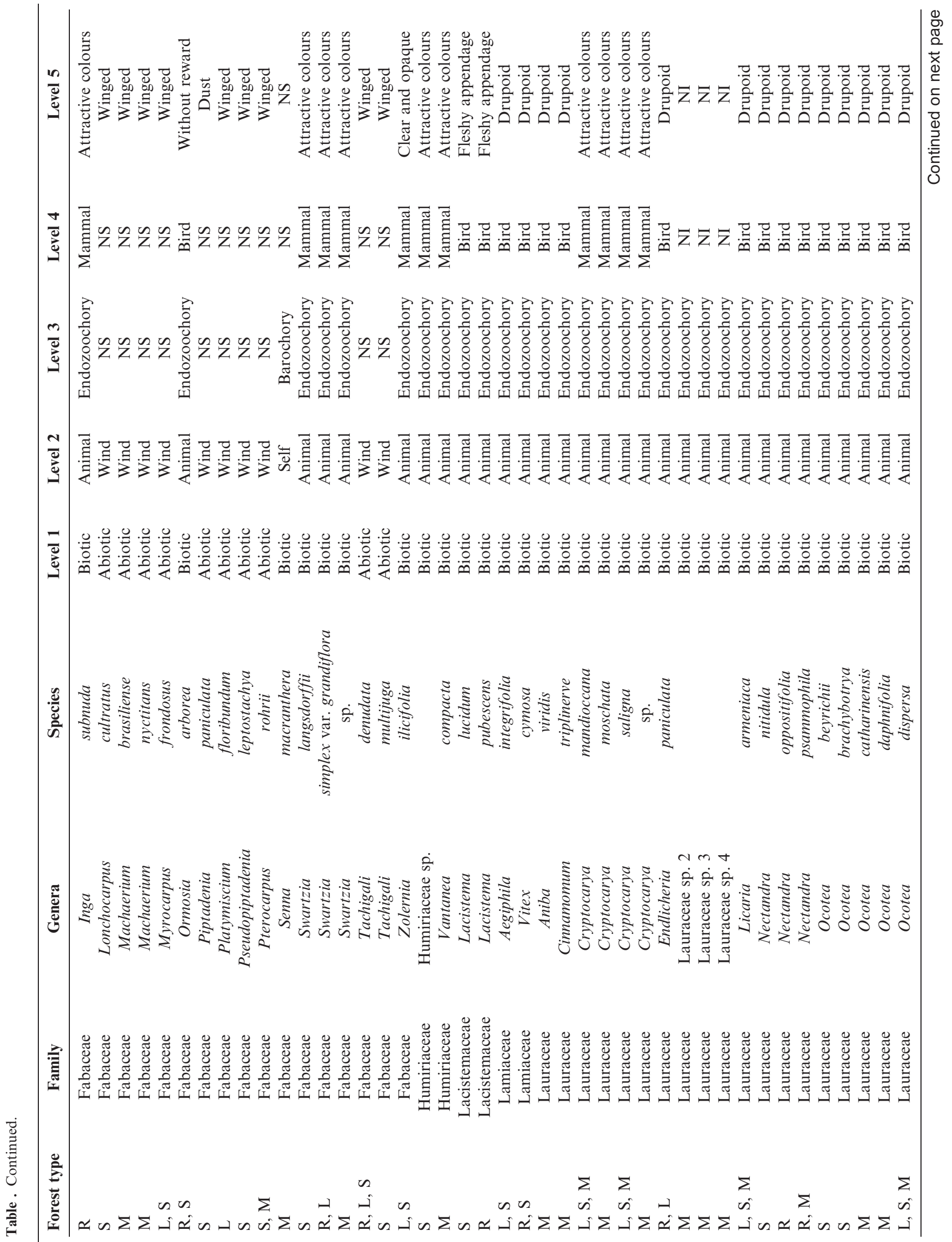




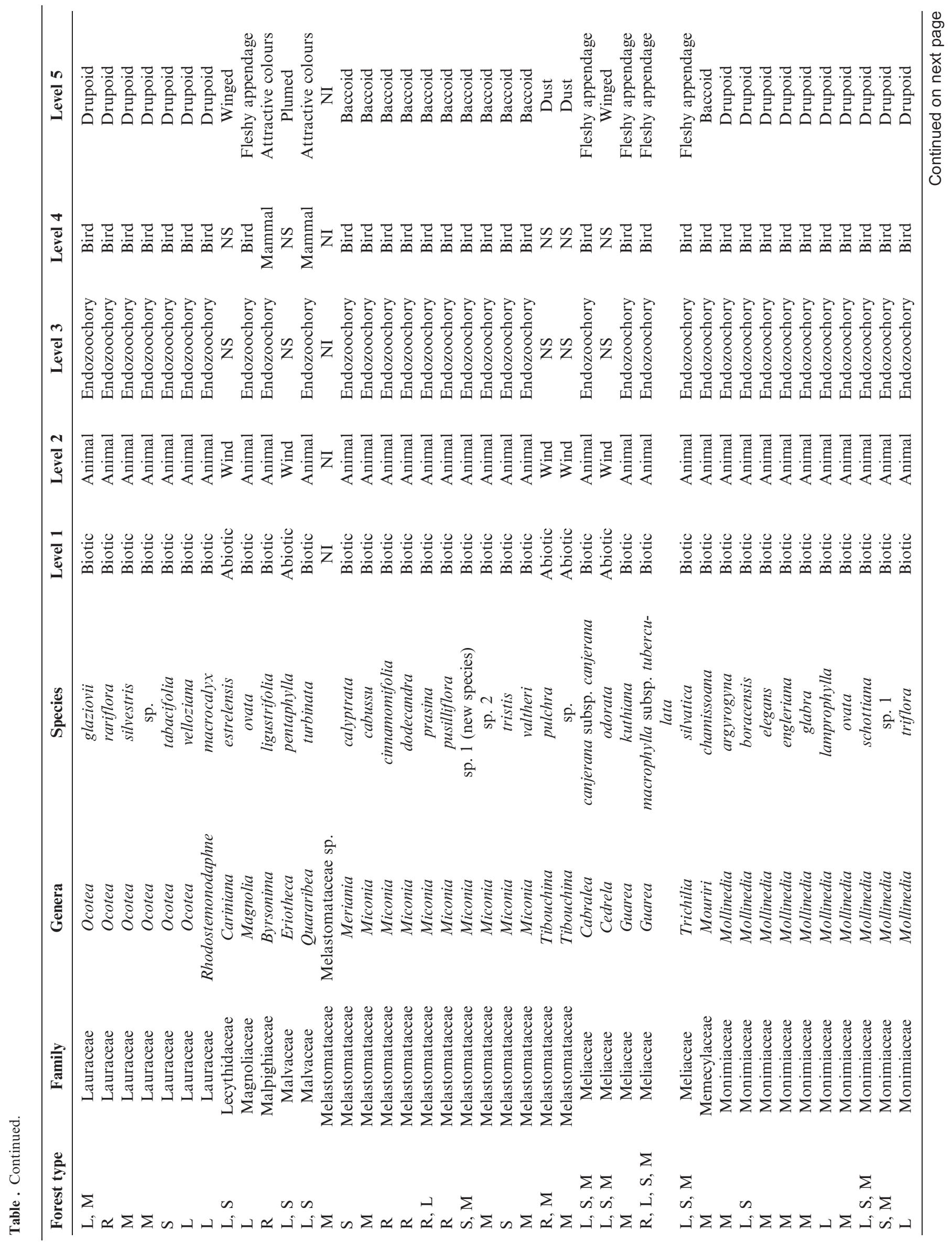




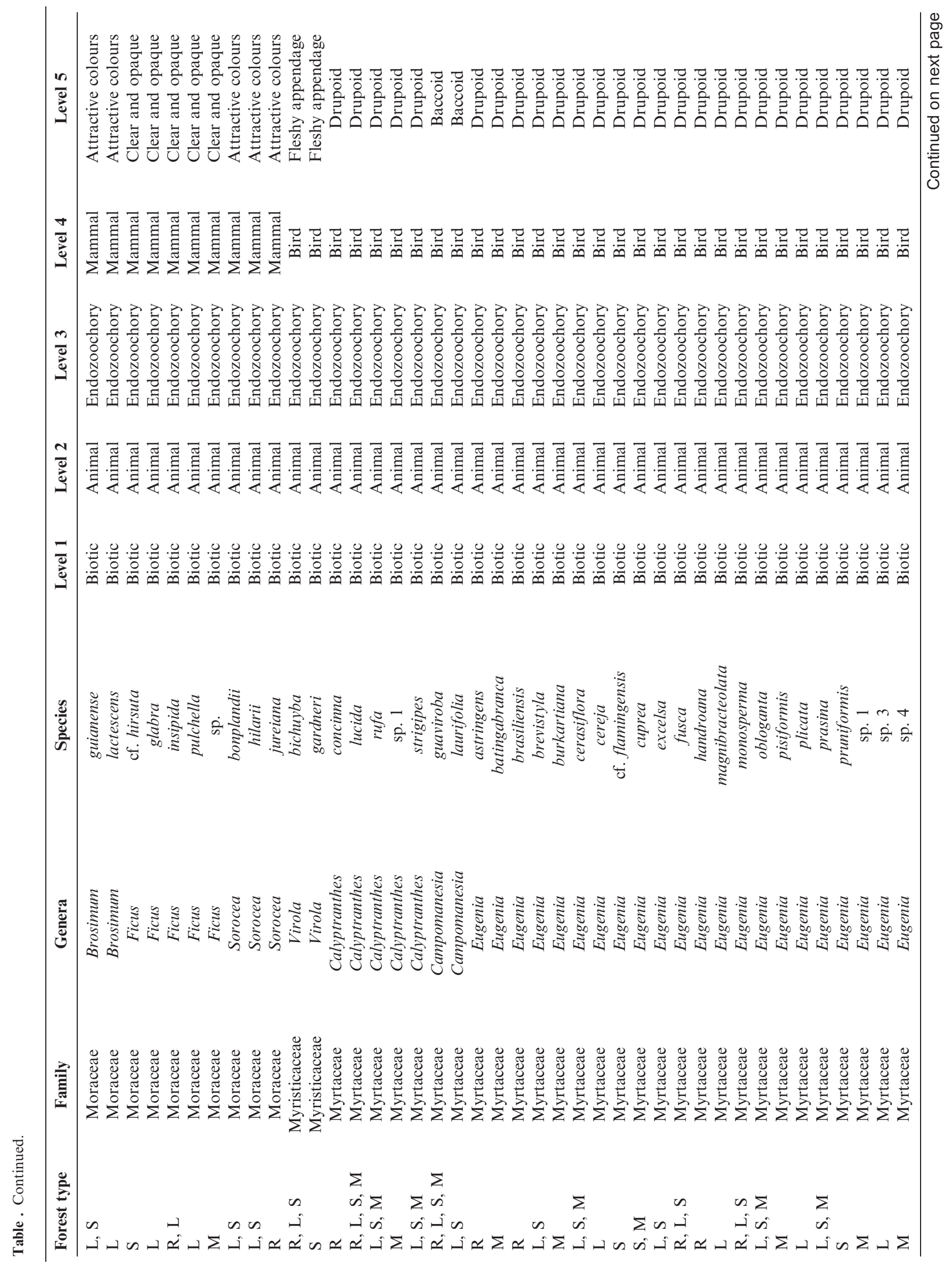




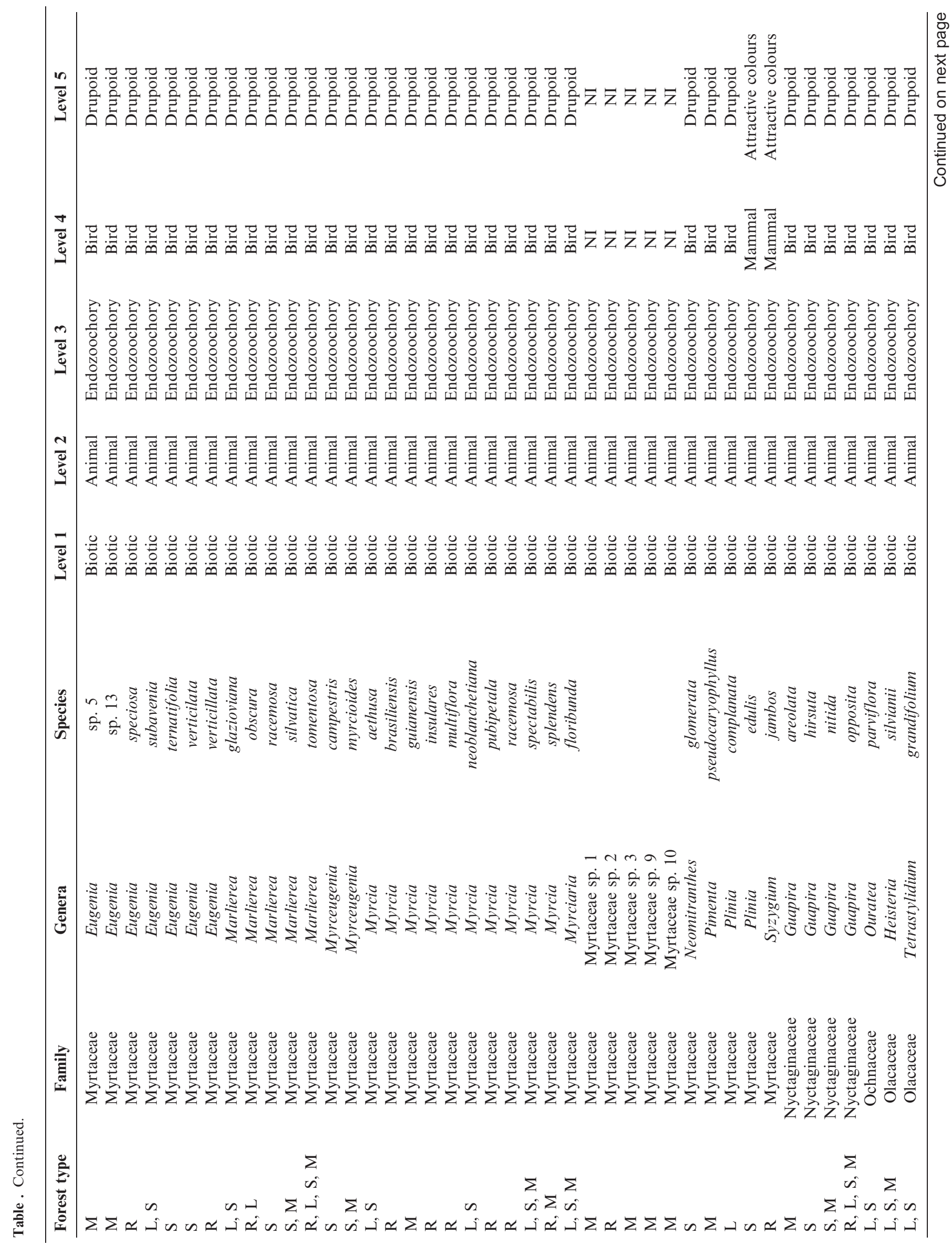




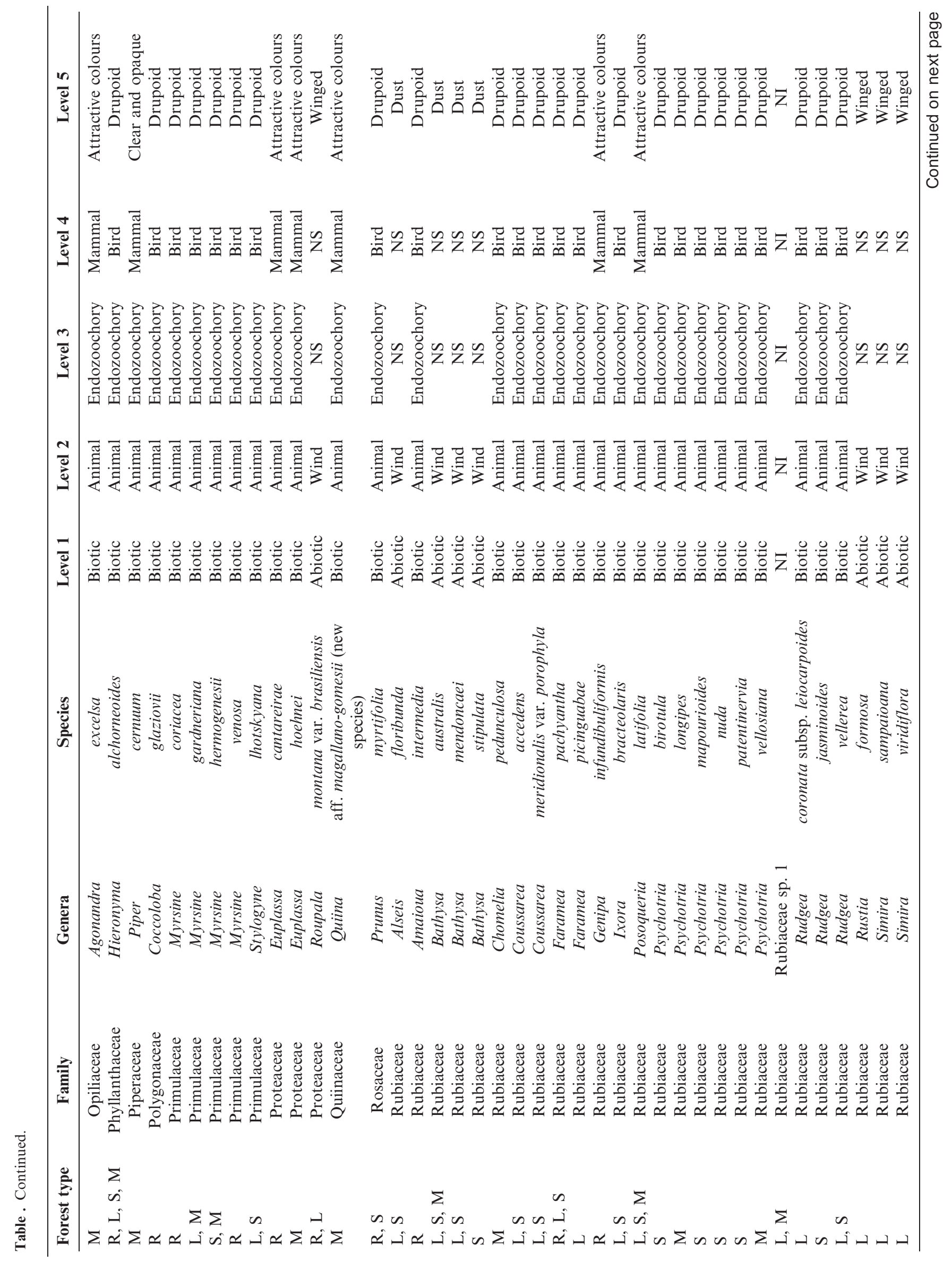




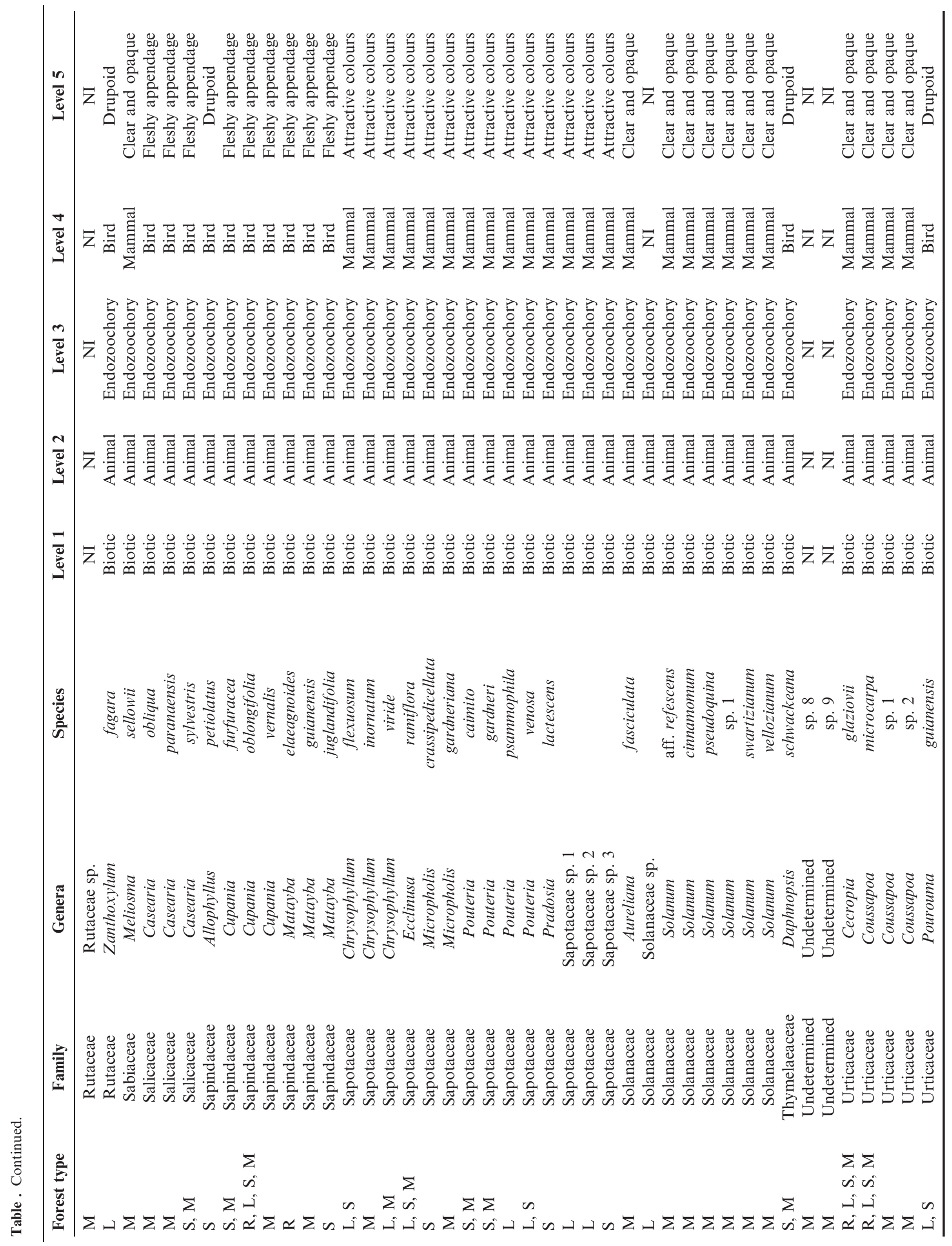

